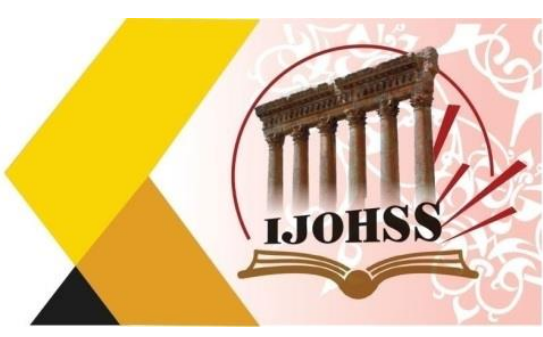

\title{
موقف صحافة لواء كربلاء من حركة مايس 1941
}

\author{
د. د. خلف عبيد حمود \\ وزارة التربية/ مديرية تربية بابل فيل \\ العراق مايرية
}

kahhak401@gmail.com

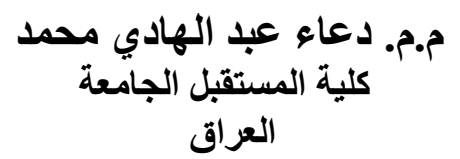

Doaaa.al-hadee@mustaqbal-college.edu.iq

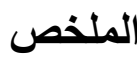

تعد الصـحافة صسورة مـن صسور الحضـارة في اي بلـد، بـل أنهـا " ركن مـن أعظم الأركـان التي تشبيد عليها

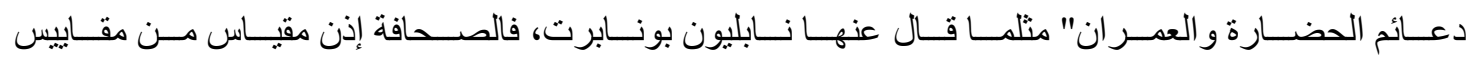
الحضــارة وروح الـبلاد وشـريانها، فالأكسـة بــا صــافة كهيكـل بـلا روح فـدور ها كبيـر فـي رقـي الثـعب

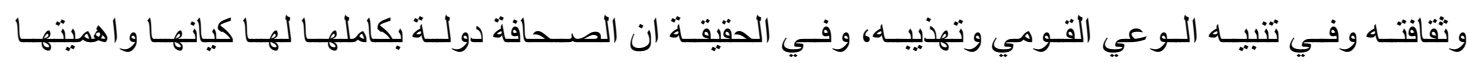
فحكومتهـا الكتـاب وشـعبها القـر اء، و إذا مـا أردنـا دراسـة تـاريخ امــة او حضــارة فعلينـا البحـث عـن صـحافتها

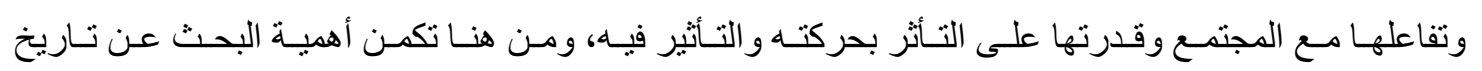
الصحافة لواء كربلاء وموقفها من الاحداث السياسية في العراق. الكلمات المفتاحية: صحافة لو اء كربلاء ،حركة مايس 1941. 


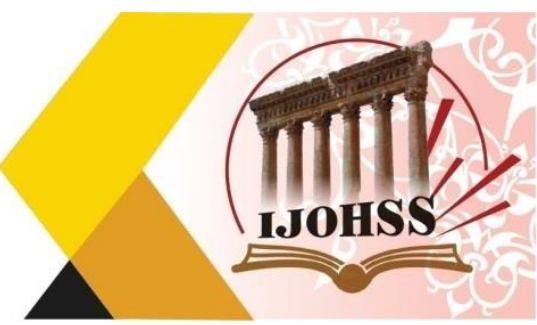

\title{
The Position of the Karbala Brigade Press on the May 1941 Movement
}

\author{
Doaa Abd AL-Hadi Mohammed \\ Al-Mustaqbal College University \\ Iraq \\ Doaaa.al-hadee@mustaqbal-college.edu.iq
}

\author{
Dr. Khalaf Obaid Hamood \\ Ministry of Education \\ Iraq \\ kahhak401@gmail.com
}

\begin{abstract}
The press is a form of civilization in any country, but rather it is "one of the greatest pillars upon which the pillars of civilization and urbanization are built," as Napoleon Bonaparte said about it. The people and their culture and in alerting and educating the national consciousness. In fact, the press is an entire state that has its entity and importance, its government is writers and its people are readers. If we want to study the history of a nation or civilization, we must search for its press, its interaction with society and its ability to be affected by its movement and influence on it, hence the importance of searching for The history of the press, the Karbala Brigade, and its position on political events in Iraq.
\end{abstract}

Keywords: Karbala Brigade press, May movement 1941. 


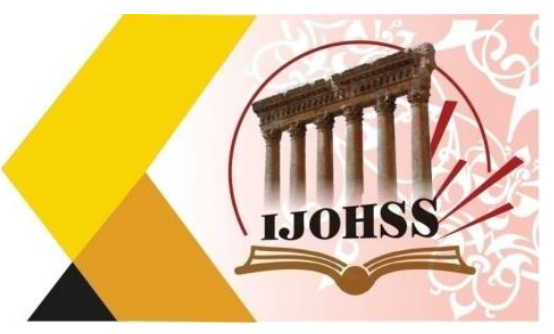

المقدمة

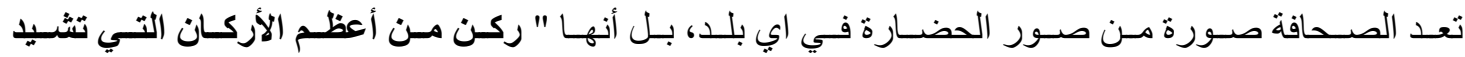

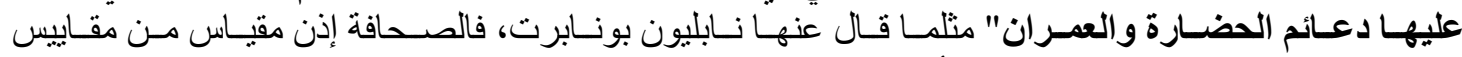

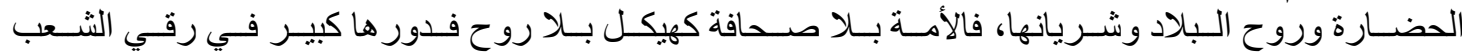

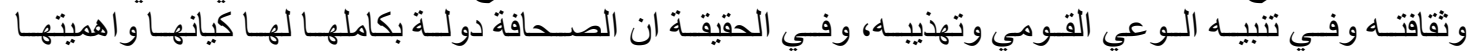

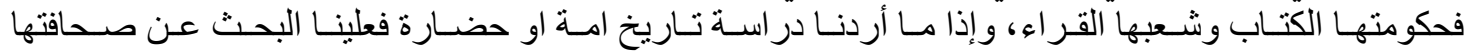

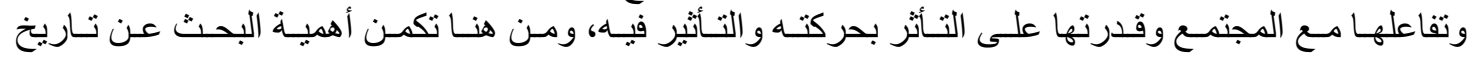

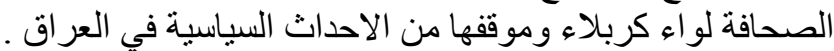

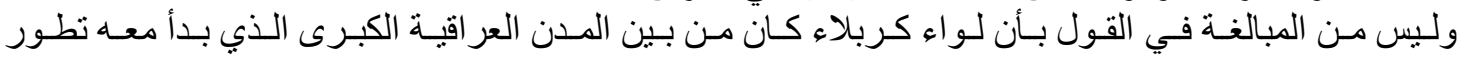

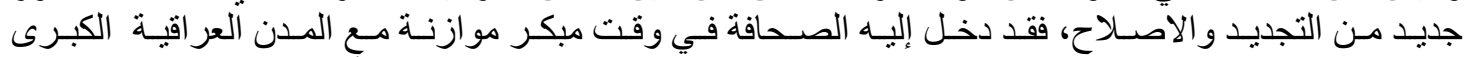

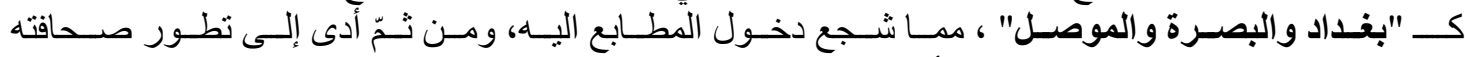

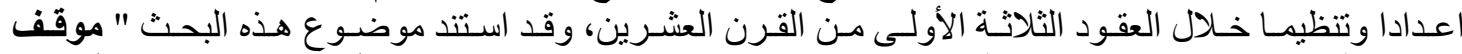

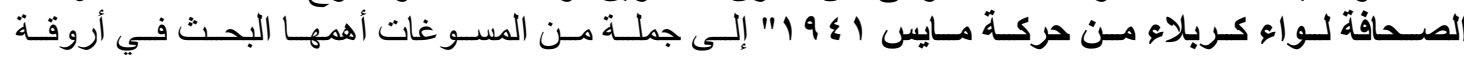

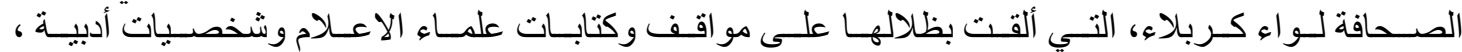

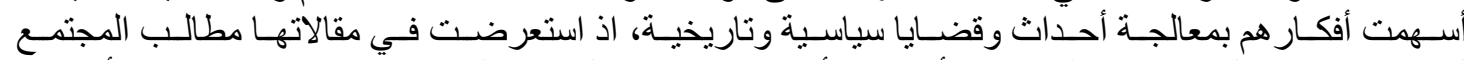

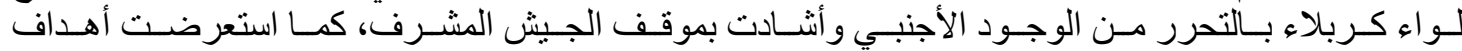

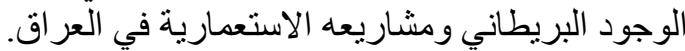

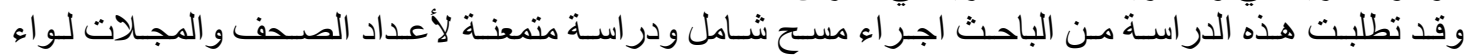

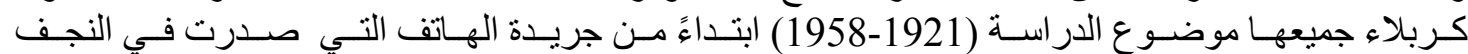

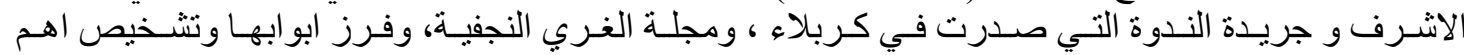

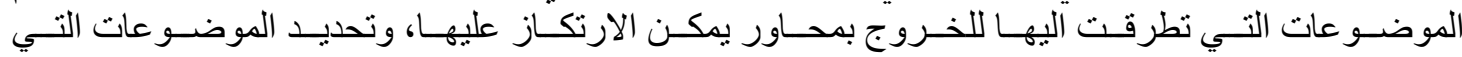
واعكن وضعها في خطة البحث.

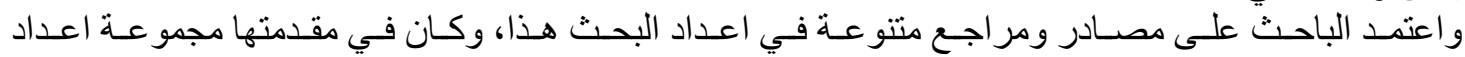

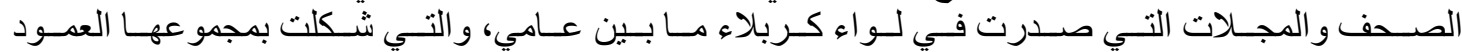

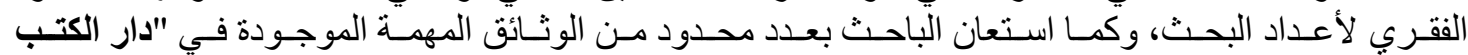

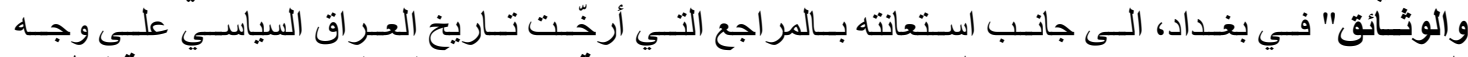

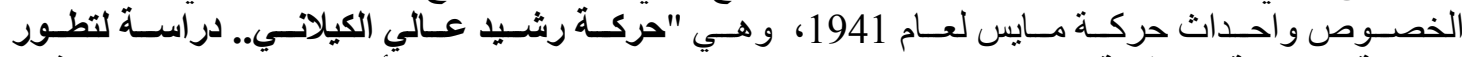

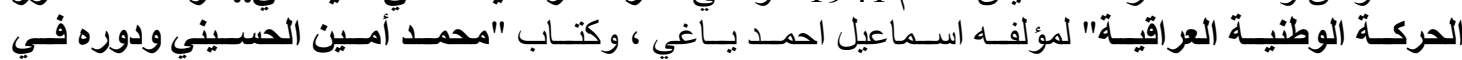

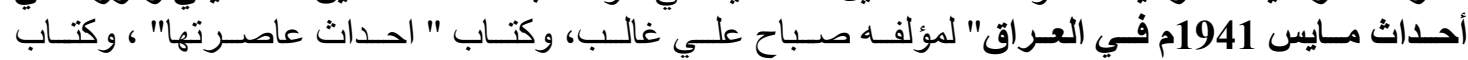

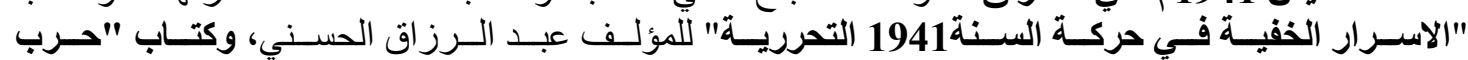
العراق 1941 " لمؤلفه يرند فئد فيليب شرويدر.

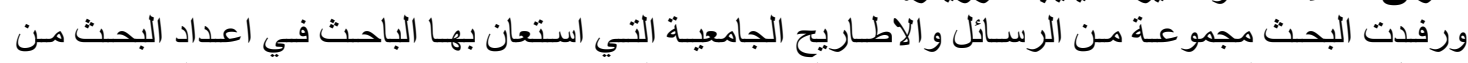

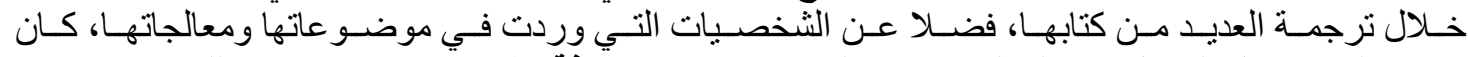

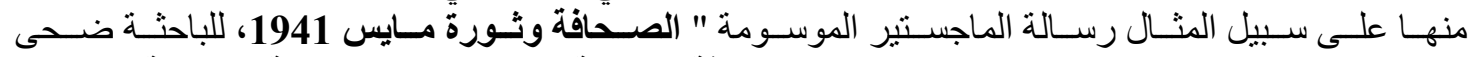

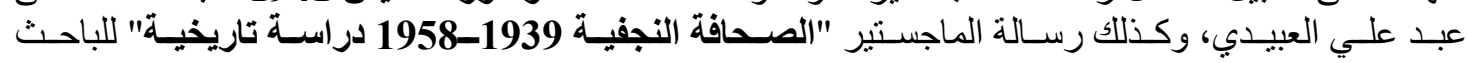

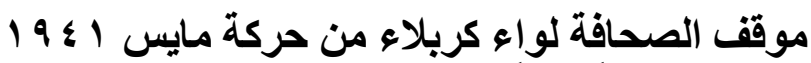

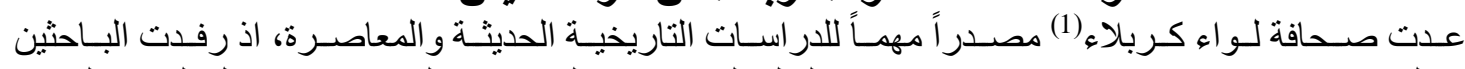

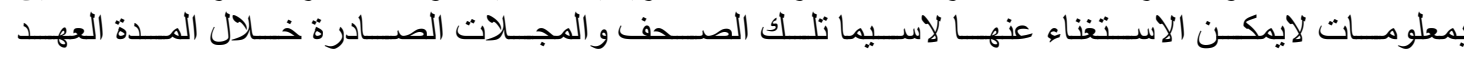

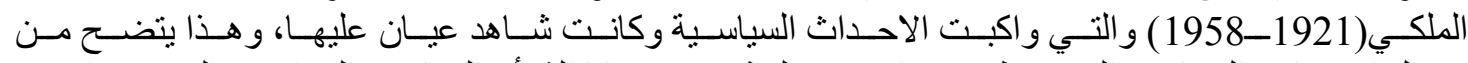

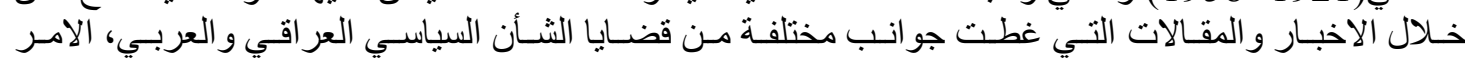




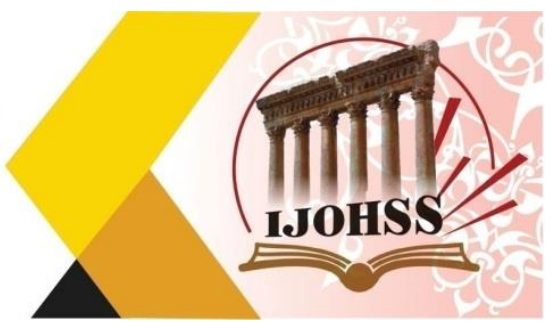

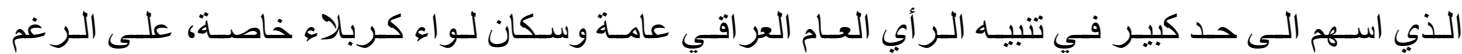

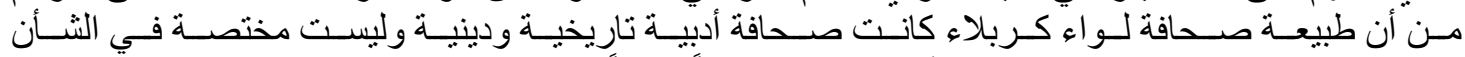

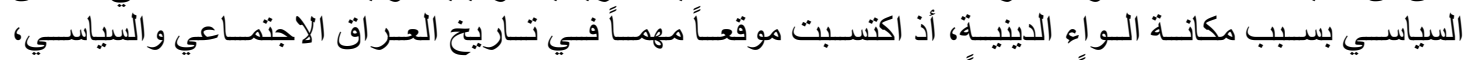

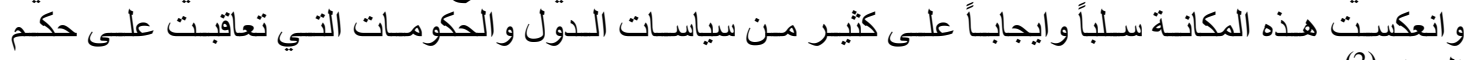
العراق (2) (2)

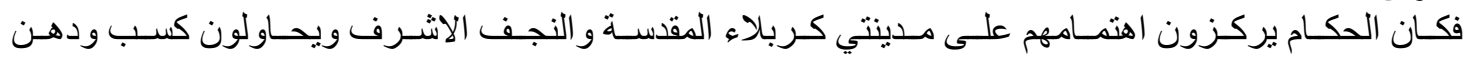

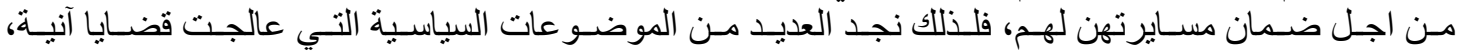

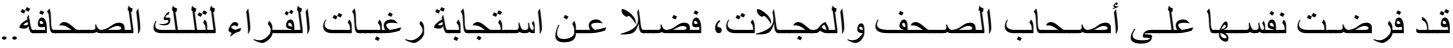

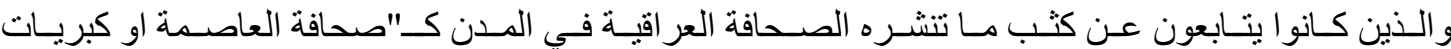

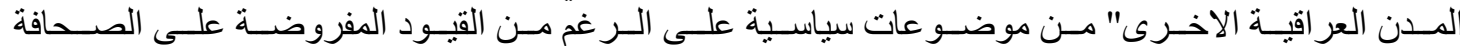

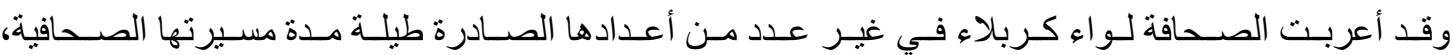

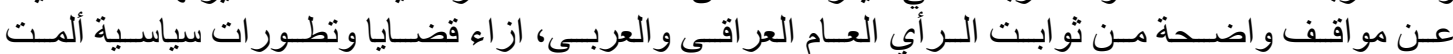

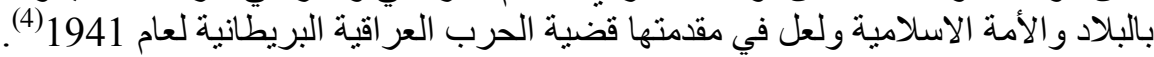

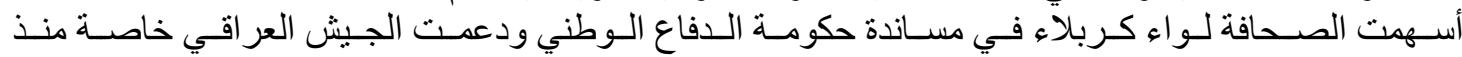

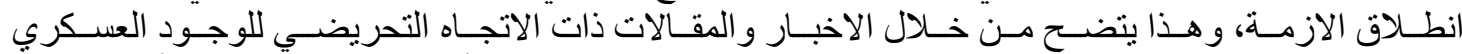

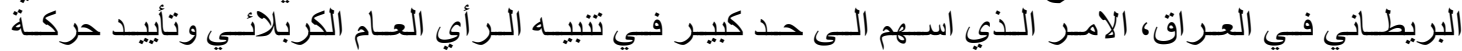

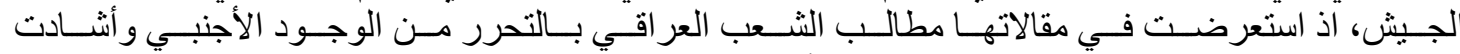

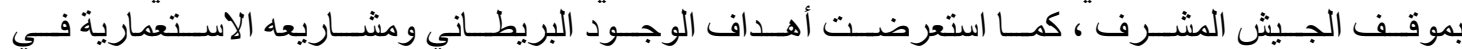
العر اق (5)

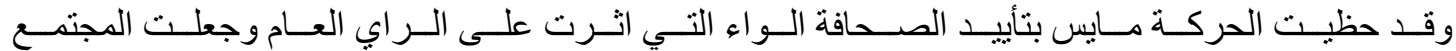

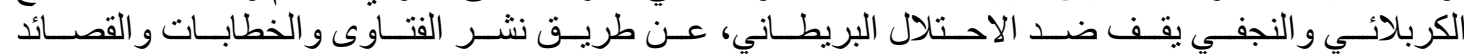

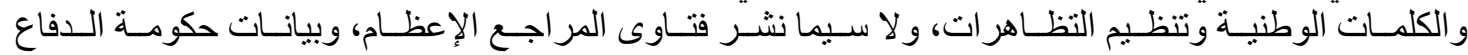

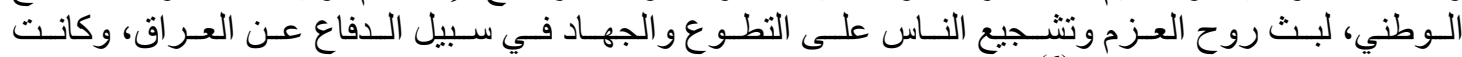

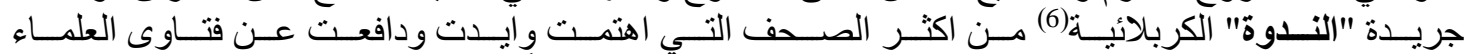

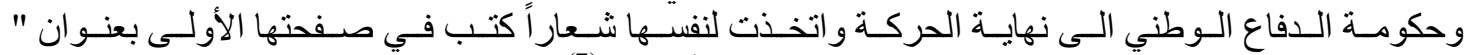

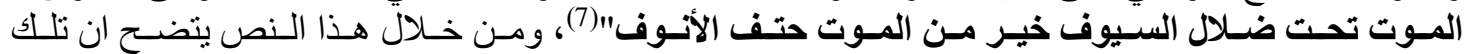

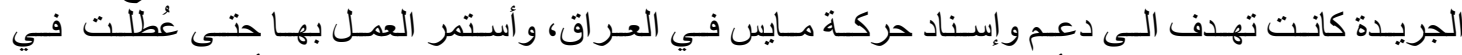

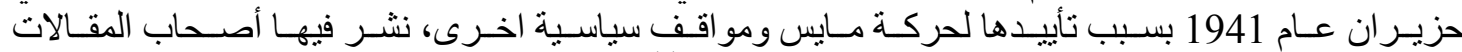

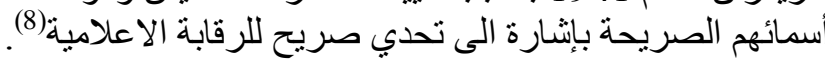

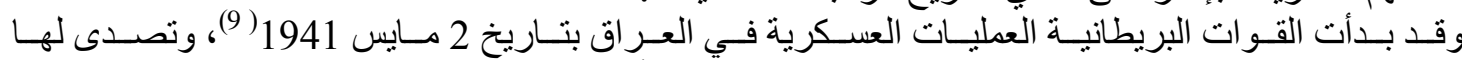

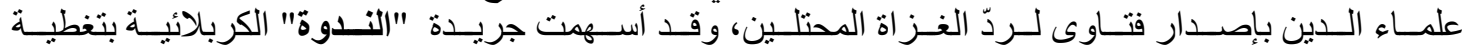

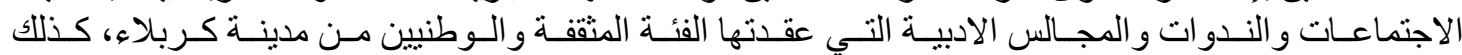

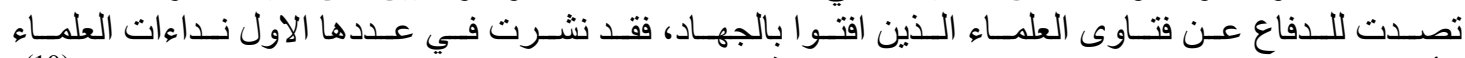

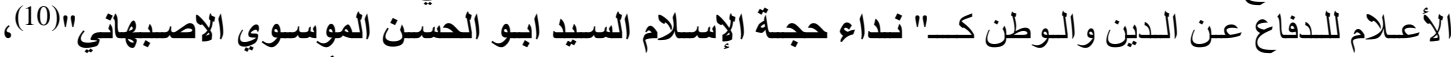

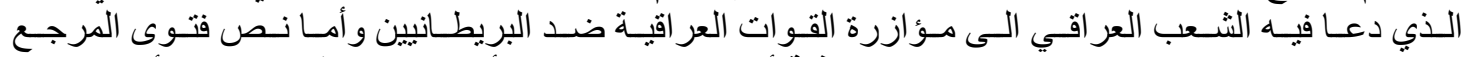

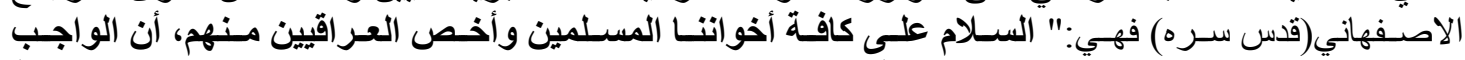

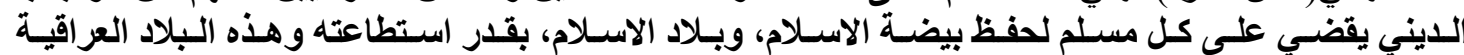

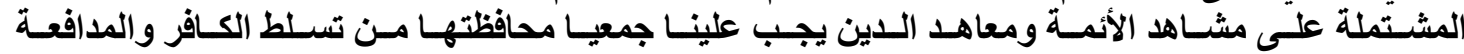

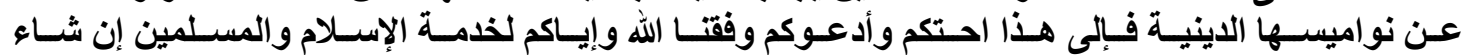

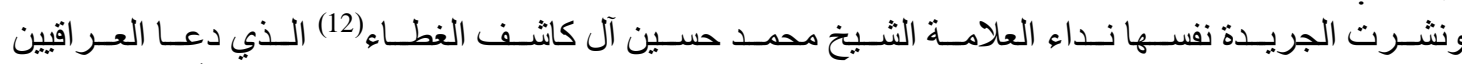

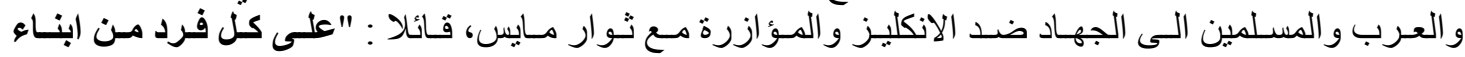




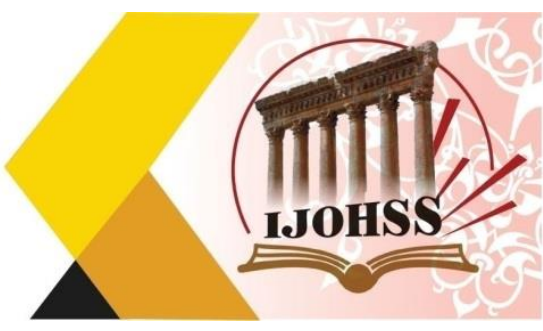

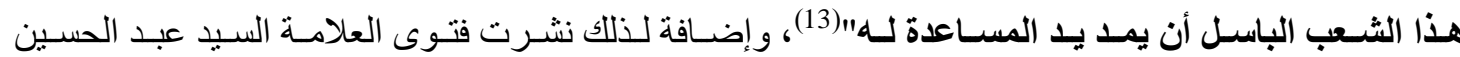

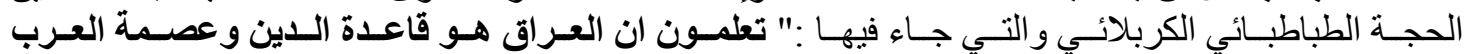

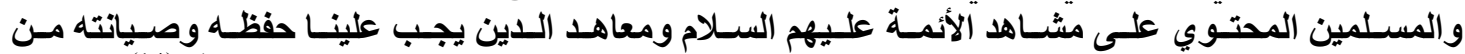

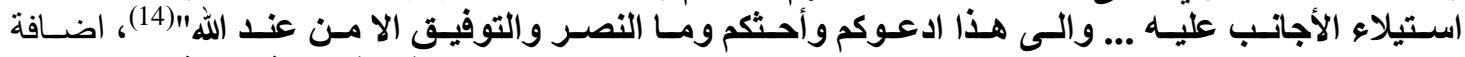

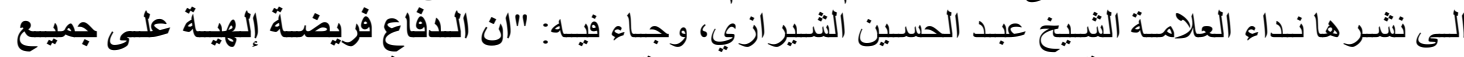

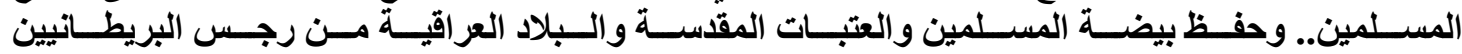

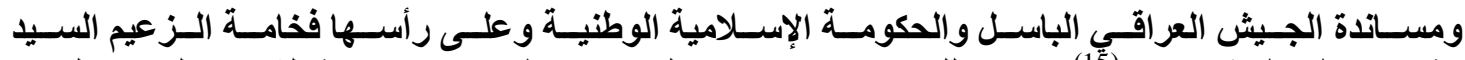

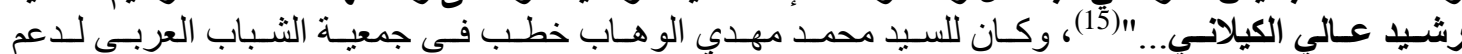

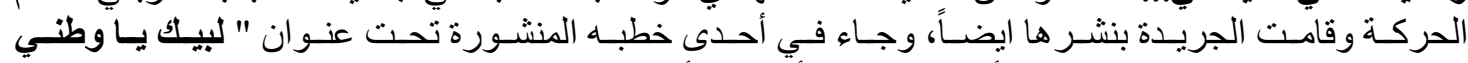

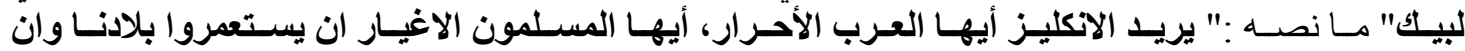

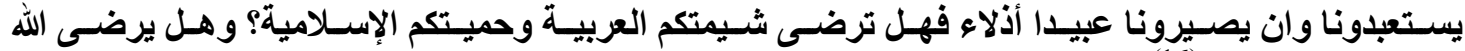
ورسوله عليكم ذلك "(16).

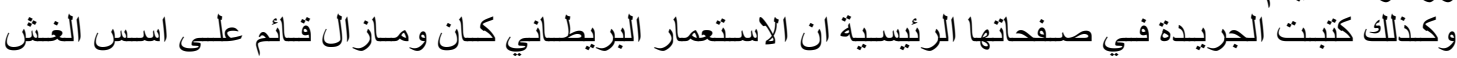

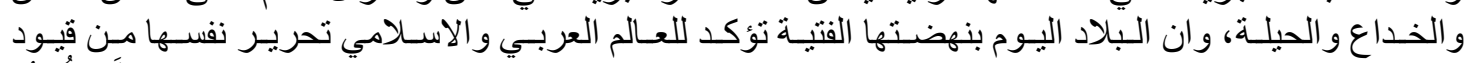

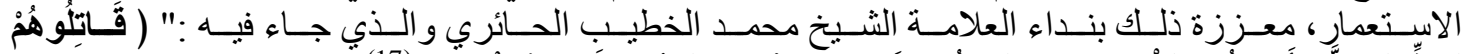

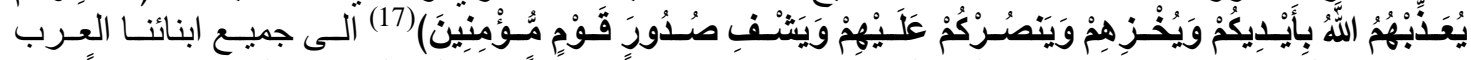

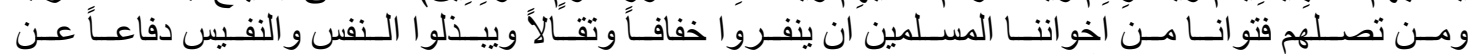

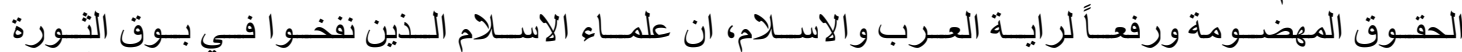

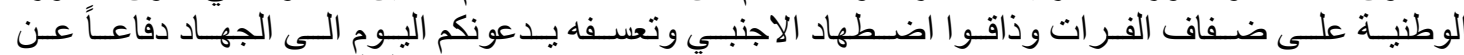

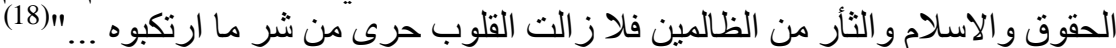

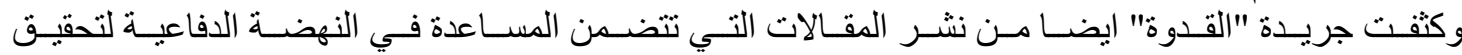

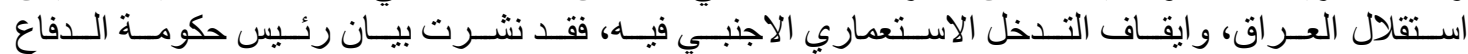

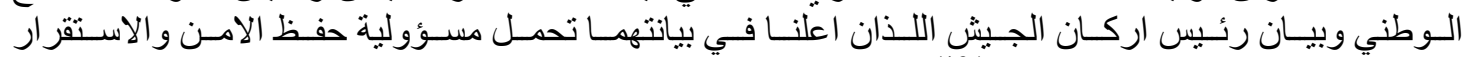

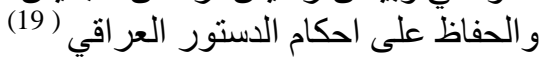

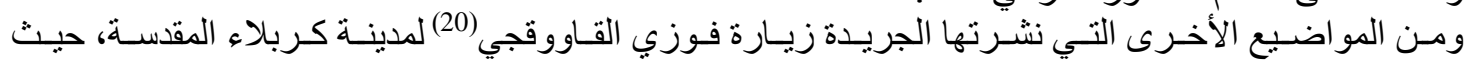

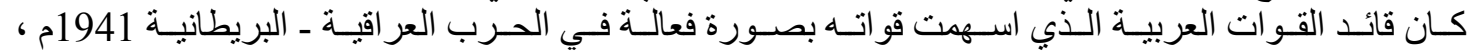

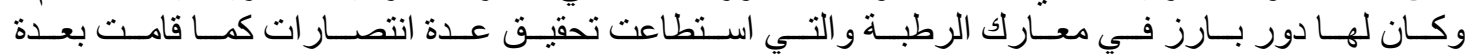

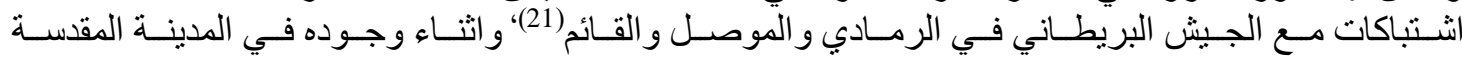

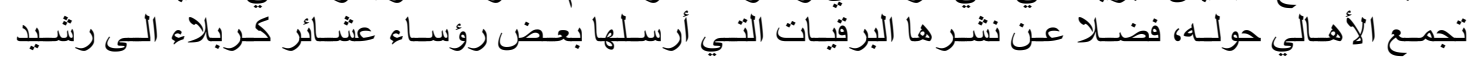

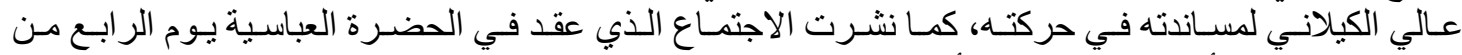

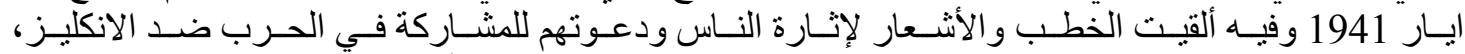

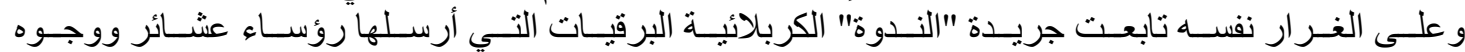
كربلاء (22)

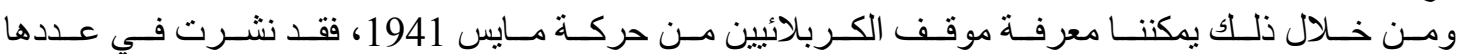

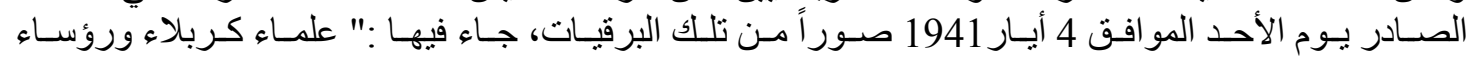

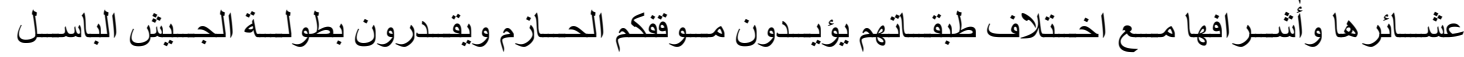

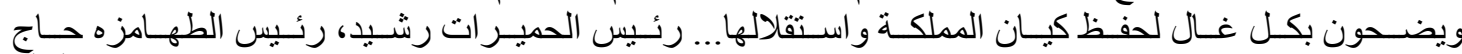

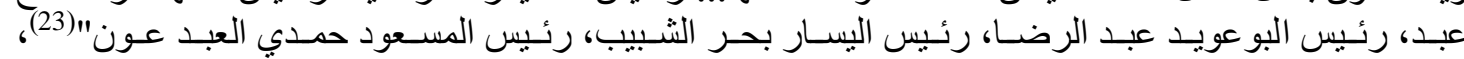

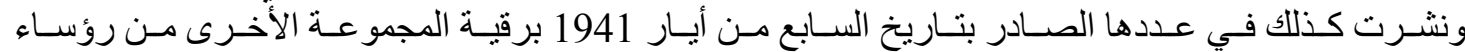

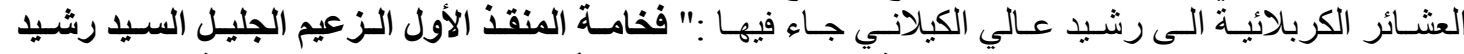

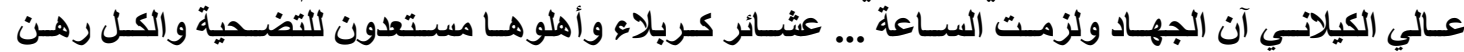

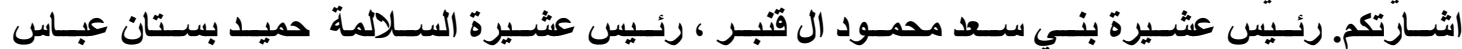
الكريم..." (24). 


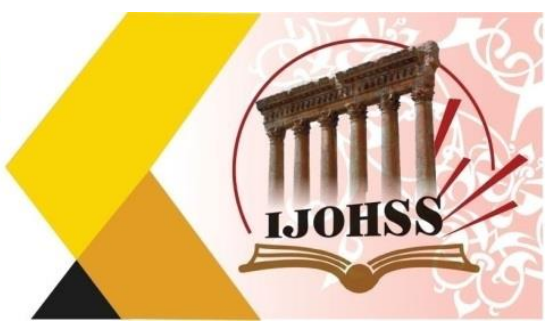

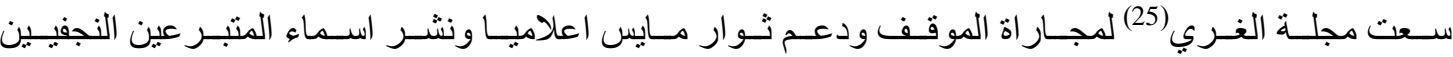

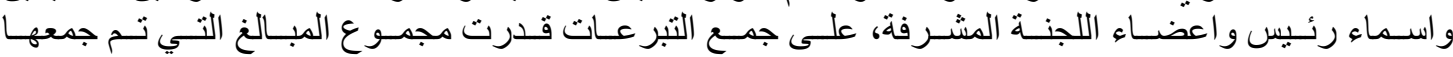

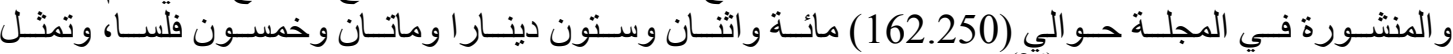

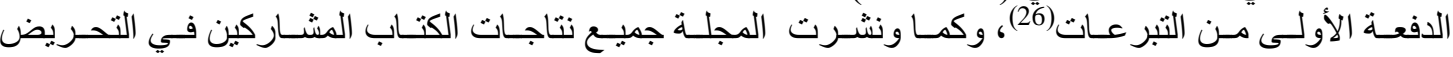

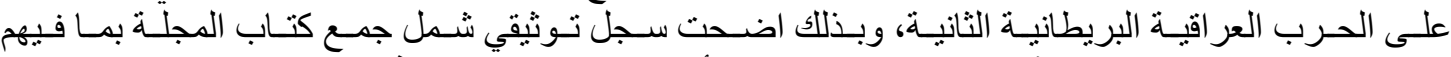

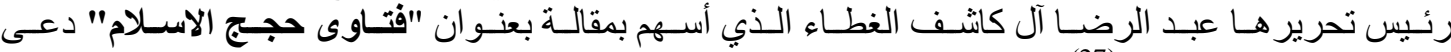
العر اقيين الى حمل السلاح (27).

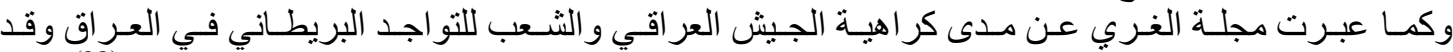

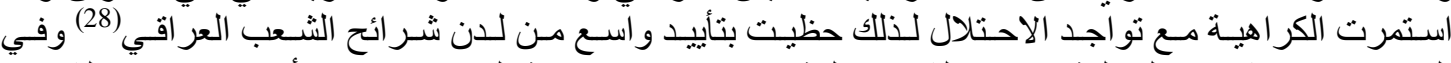

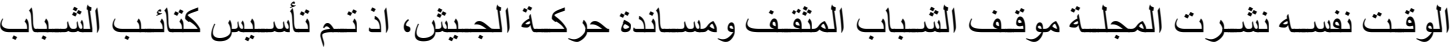

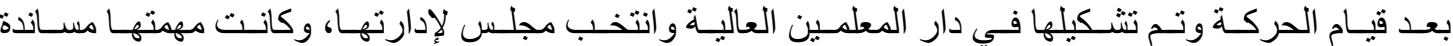

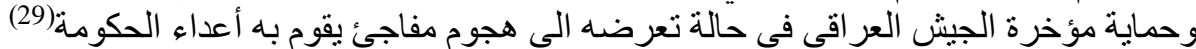

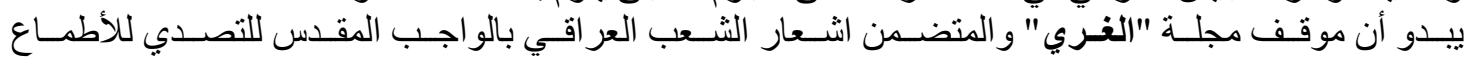

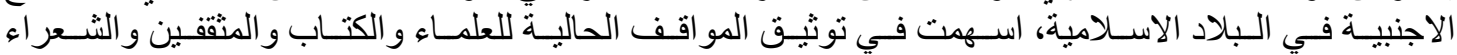

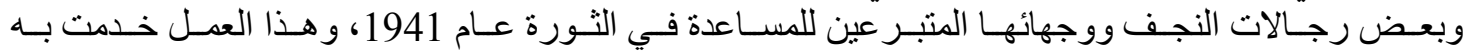

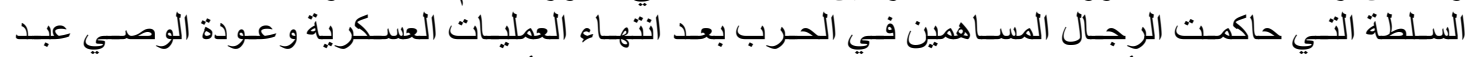

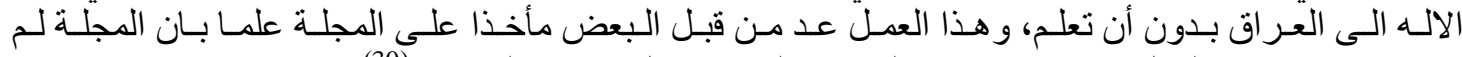

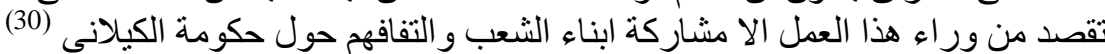

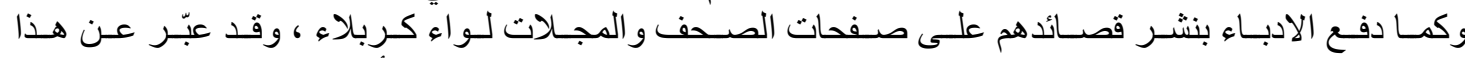

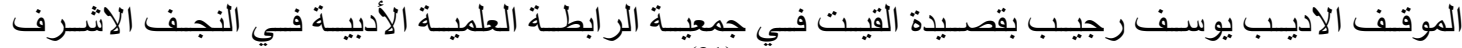

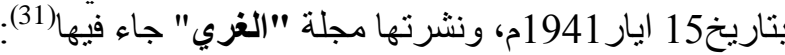

ومن يخترم لا تتبعه اللو ائم

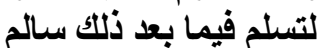

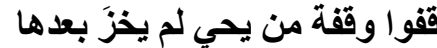

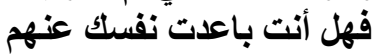

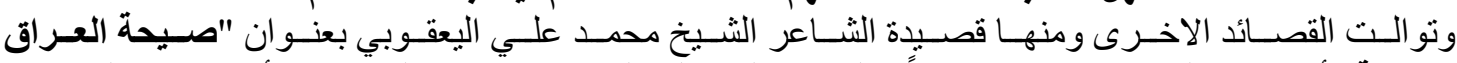

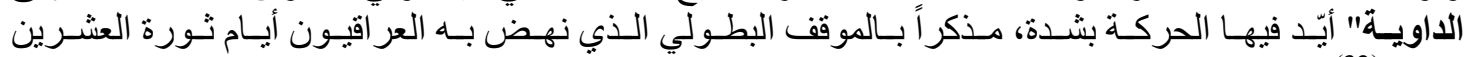

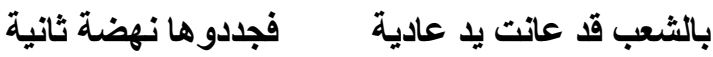

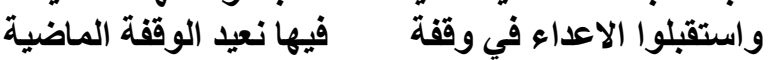

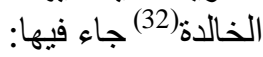

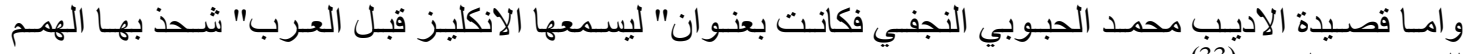

واشحذ ظباك فهذي ساعة الغلب

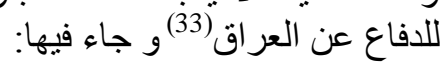

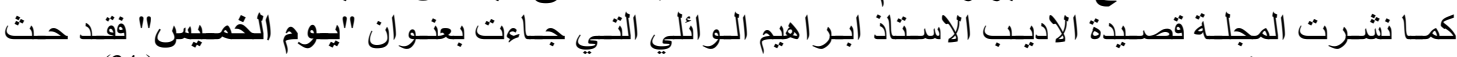

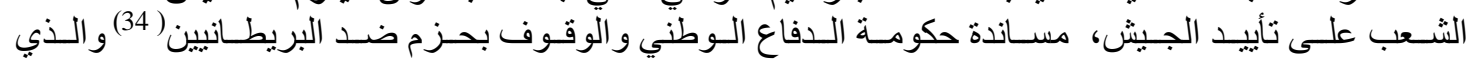

\section{لا يظفر الشعب بنيل الوطر ما لم يعزز بجيوش الظفر}

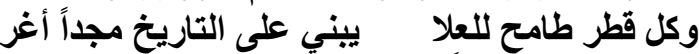

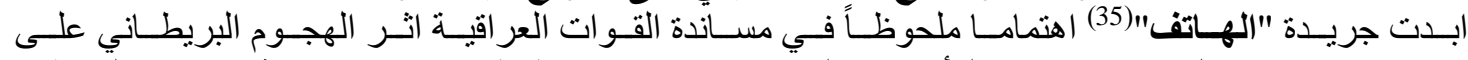

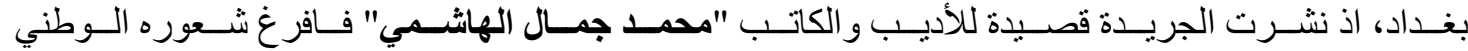

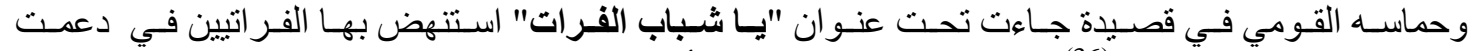

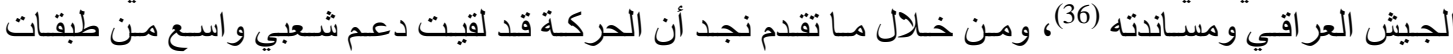

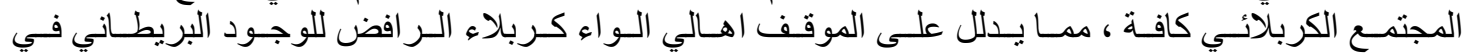
العراق. - مان. 


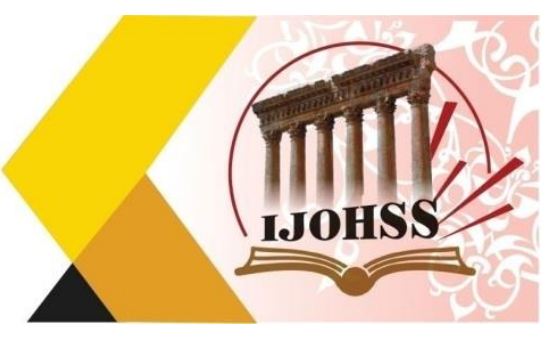

الخاتمة

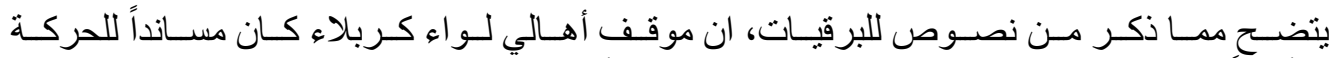

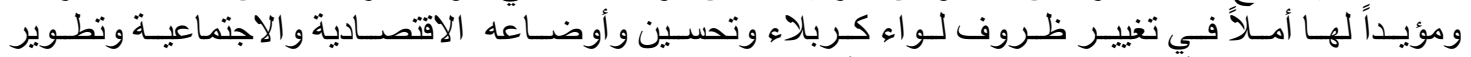

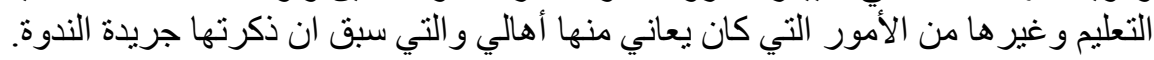

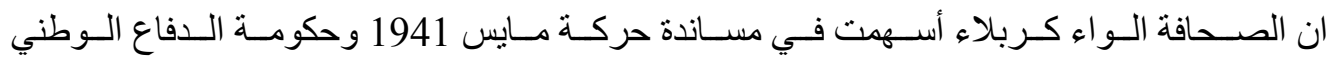

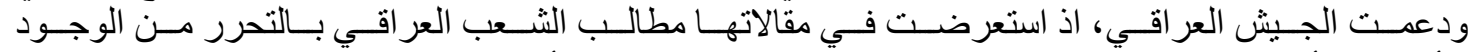

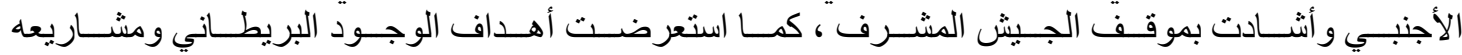

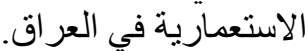

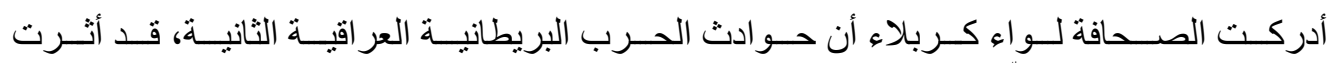

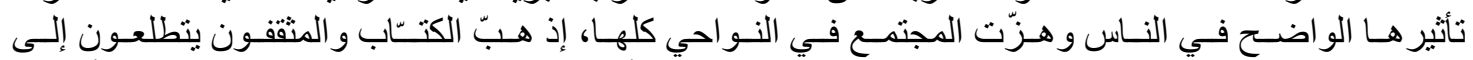

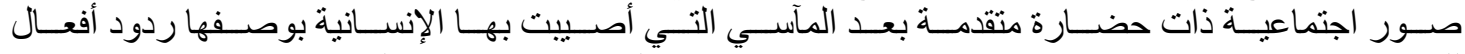

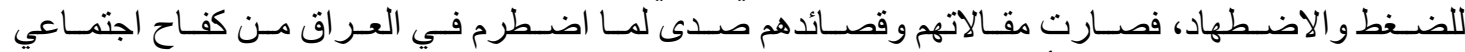
ونشاط فكري بقوة تعبير ولطف أداء، وحسن معالجة. 
المجلة الدولية اللهلور الأسانية والإمتماعية International Journal on Humanities and Social Sciences website:www.ijohss.com Email:editor@ijohss.com ISSN: 2415 - 4822

العدد(22) يوليو 2021

Volume (22) July 2021

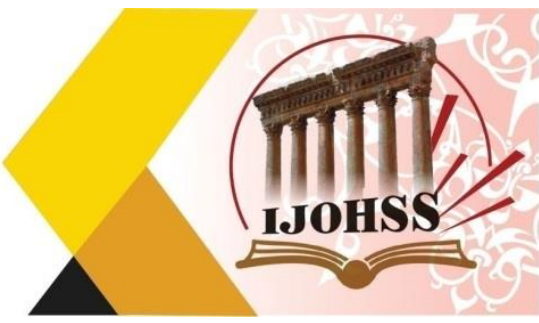

\section{الملاحق}

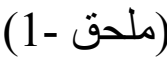

وثيقة حكومية تبين فحوى مرسوم الطوارئ الذي اعطى لرئيس الوزراء الحق في اصدار الاوامر

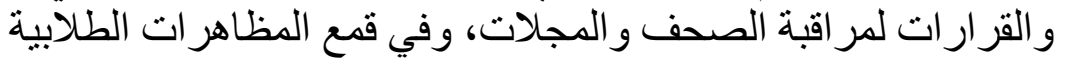

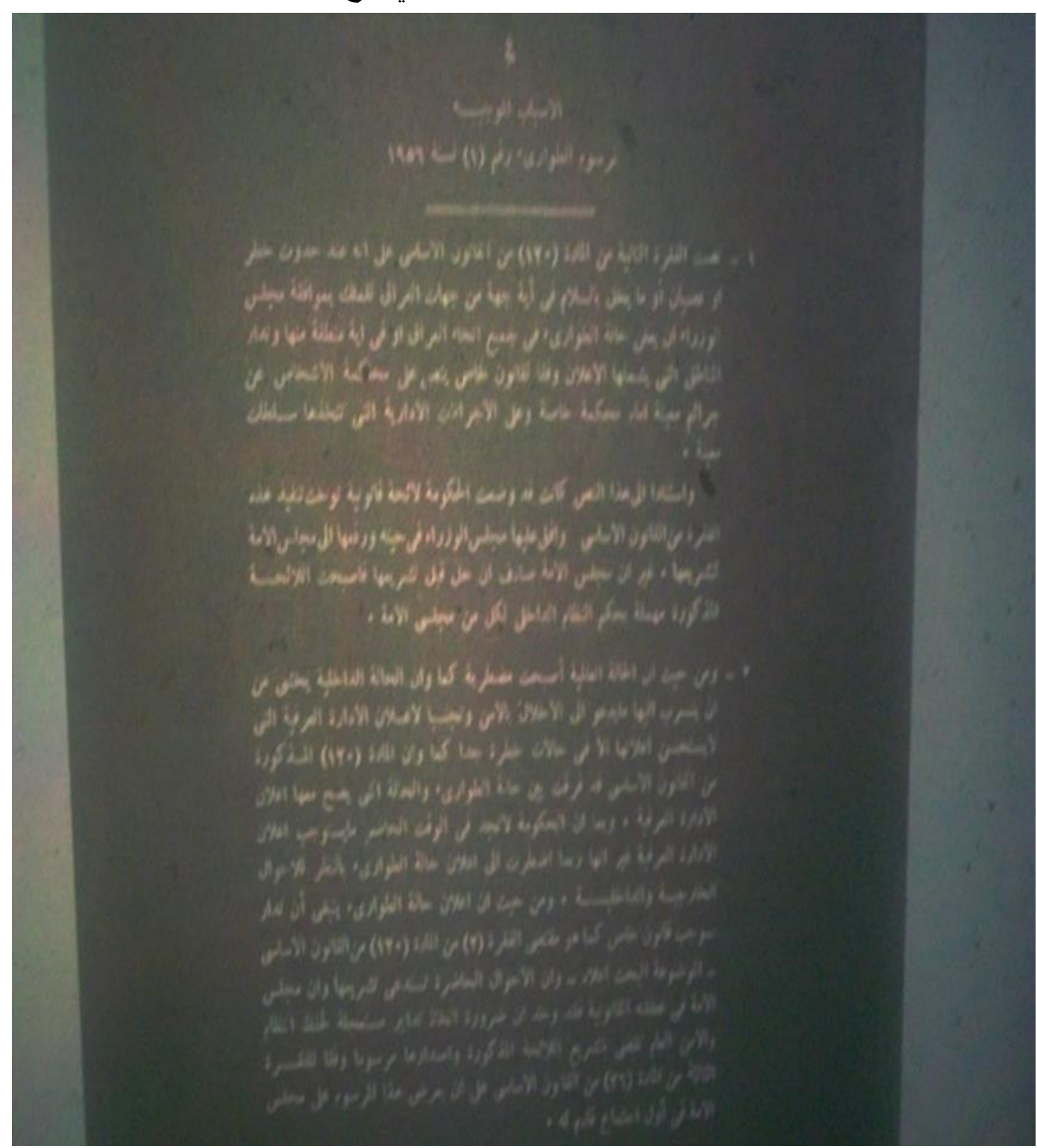


المجلة الدولية اللعلوم الإنسانية والإمتصاعية International Journal on Humanities and Social Sciences website:www.ijohss.com

Email:editor@ijohss.com

العدد(22) يوليو 2021

ISSN: 2415 - 4822

Volume (22) July 2021

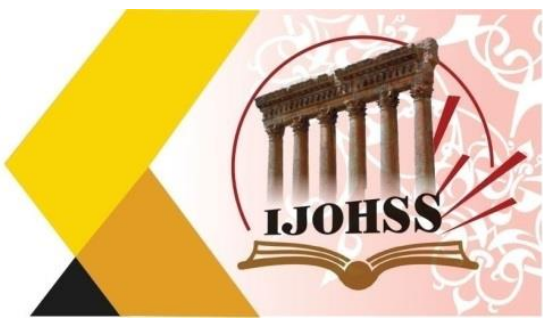

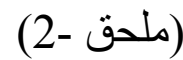

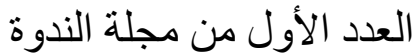

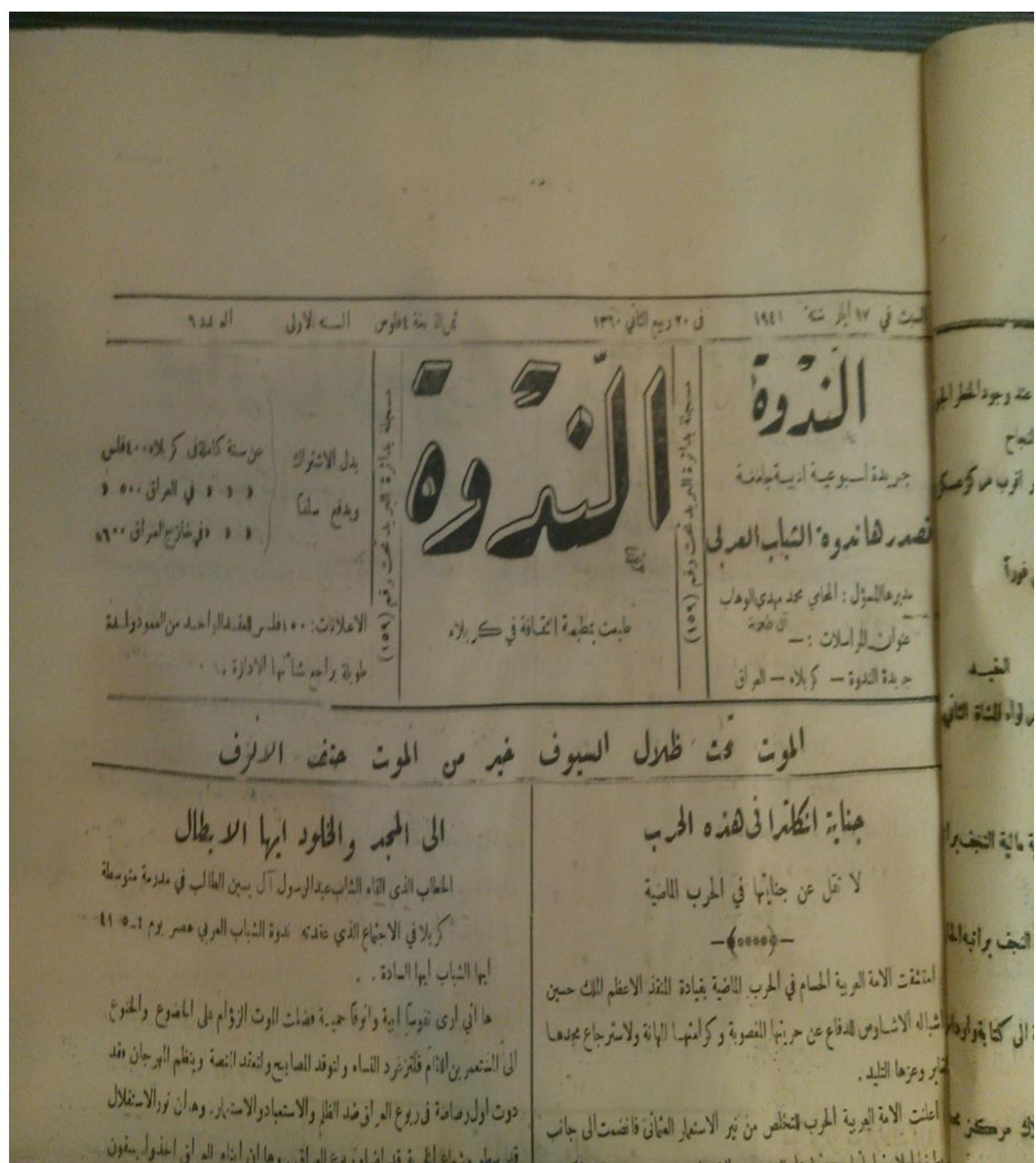


المجلة الدولية اللعلوم الإنسانية والإمتصاعية International Journal on Humanities and Social Sciences website:www.ijohss.com Email:editor@ijohss.com العدد(22) يوليو 2021 ISSN: 2415 - 4822 Volume (22) July 2021

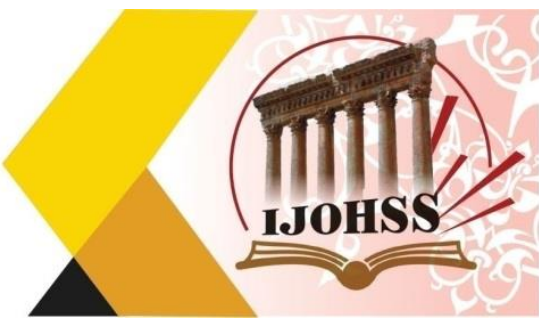

(ملحق-3)

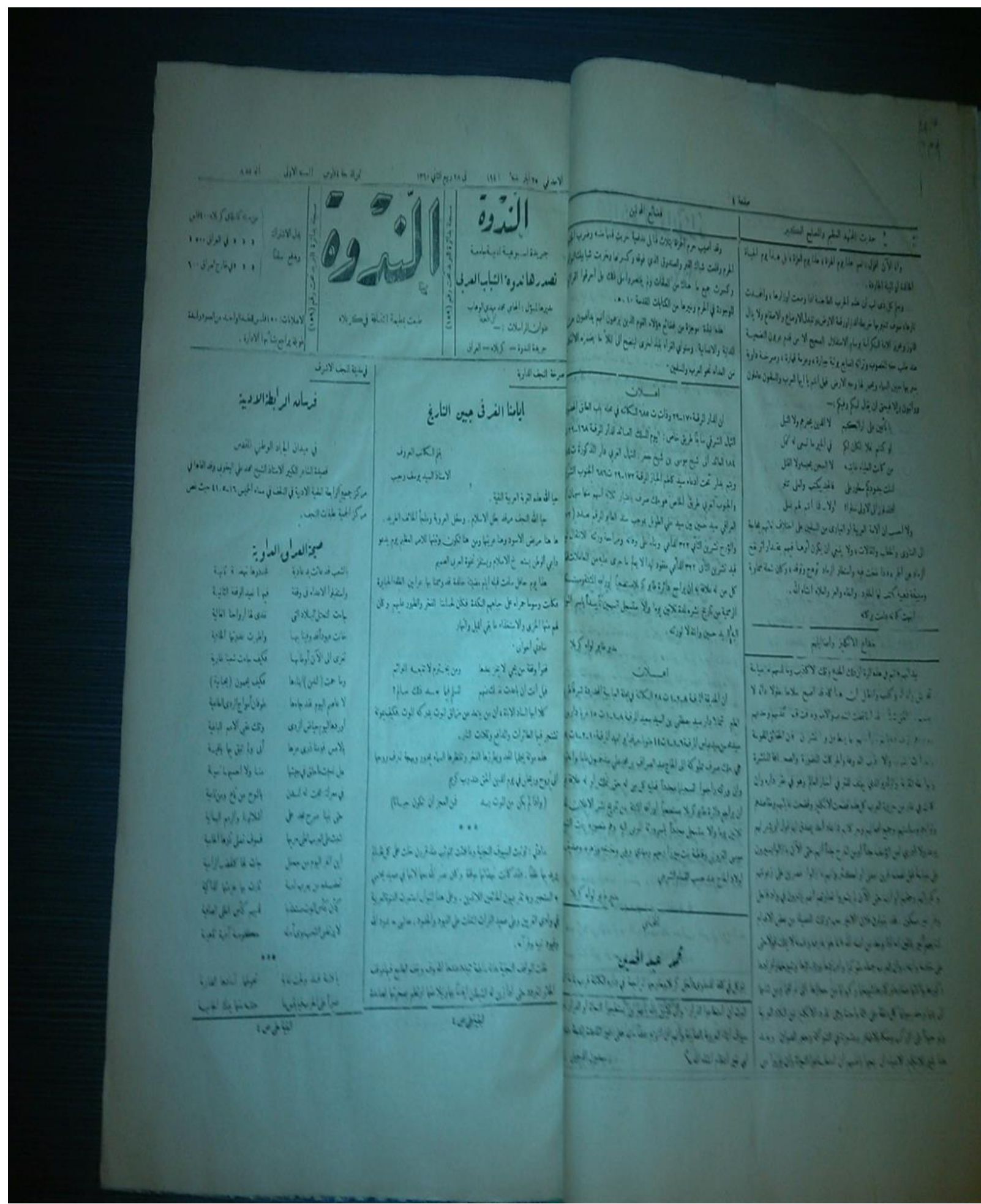


المجلة الدولية اللعلوم الإنسانية والإمتصاعية International Journal on Humanities and Social Sciences website:www.ijohss.com Email:editor@ijohss.com ISSN: 2415 - 4822

العدد(22) يوليو 2021

Volume (22) July 2021

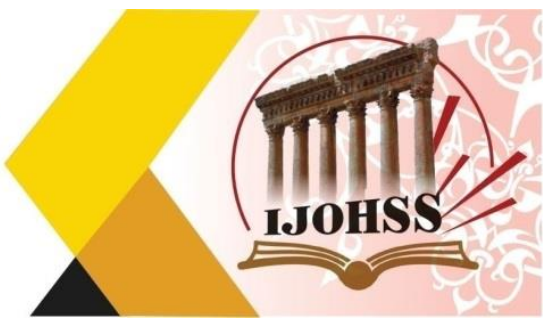

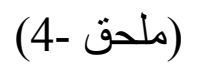

نداءآت العلماء الاعلام في لو اء كربلاء

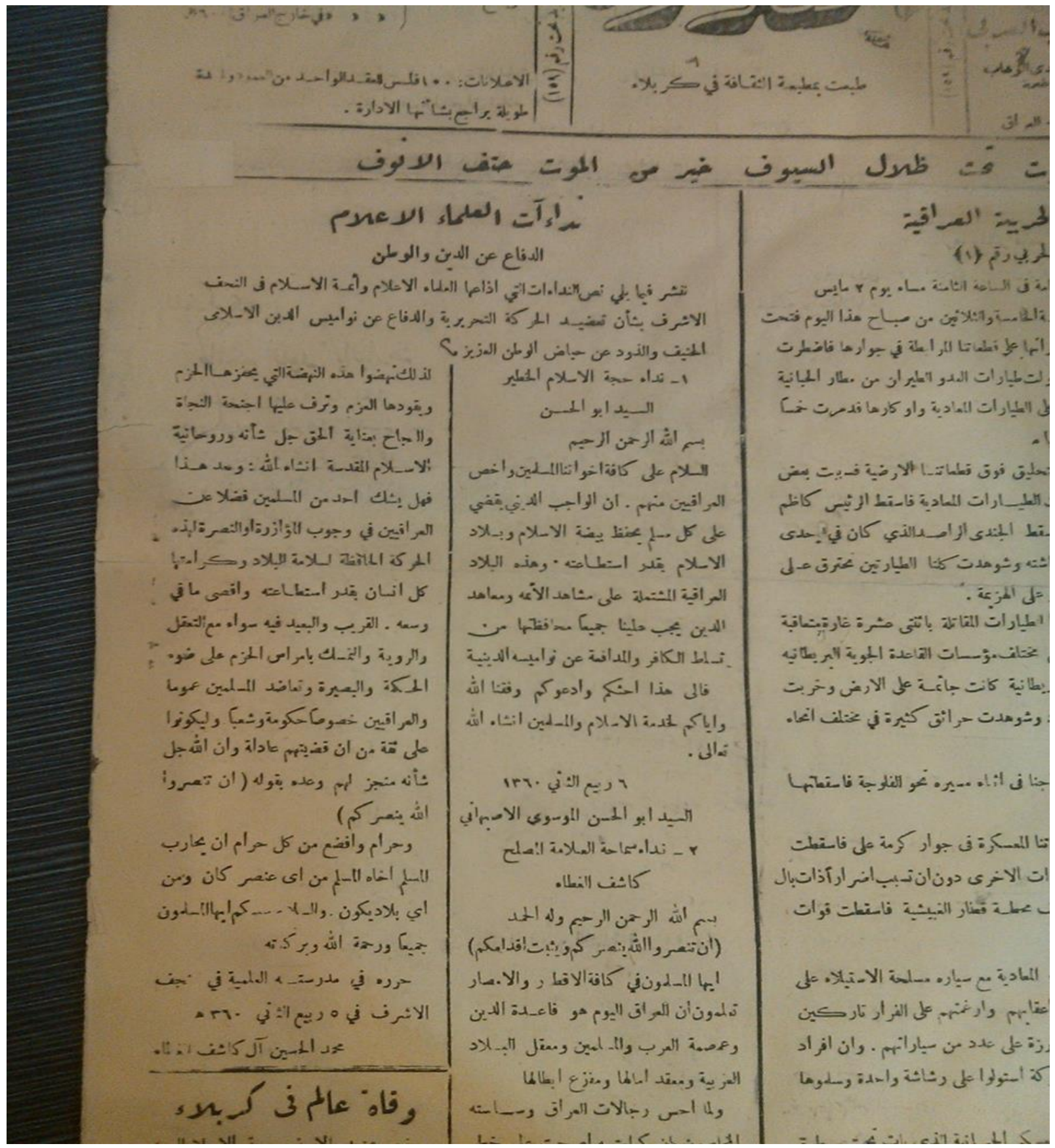


المجلة اللدولية اللملوم الإنسانية والإمتصاعية International Journal on Humanities and Social Sciences website:www.ijohss.com Email:editor@ijohss.com العدد(22) يوليو 2021 ISSN: $2415-4822$

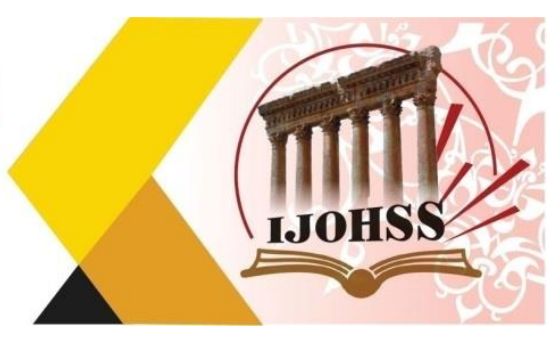

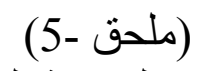

الفتاوي الخاصة بالحرب العر اقية البريطانية عام 1941 م

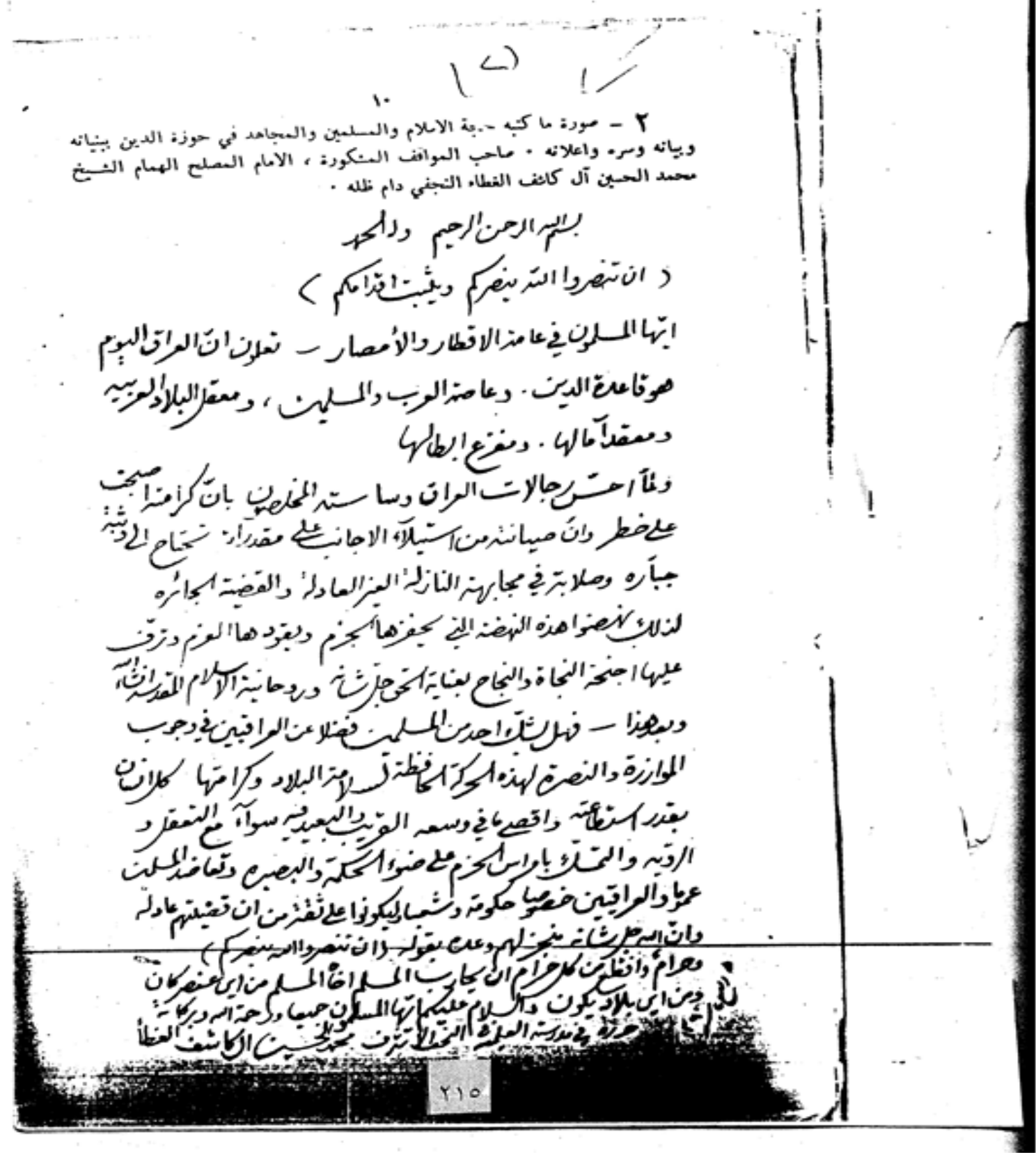


المجلة اللدولية اللملوم الإنسانية والإمتصاعية International Journal on Humanities and Social Sciences website:www.ijohss.com Email:editor@ijohss.com العدد(22) يوليو 2021 ISSN: 2415 - 4822

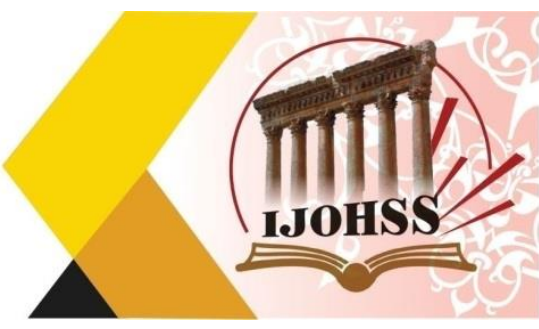

(ملحق-6)

العدد الأول من مجلة الغري

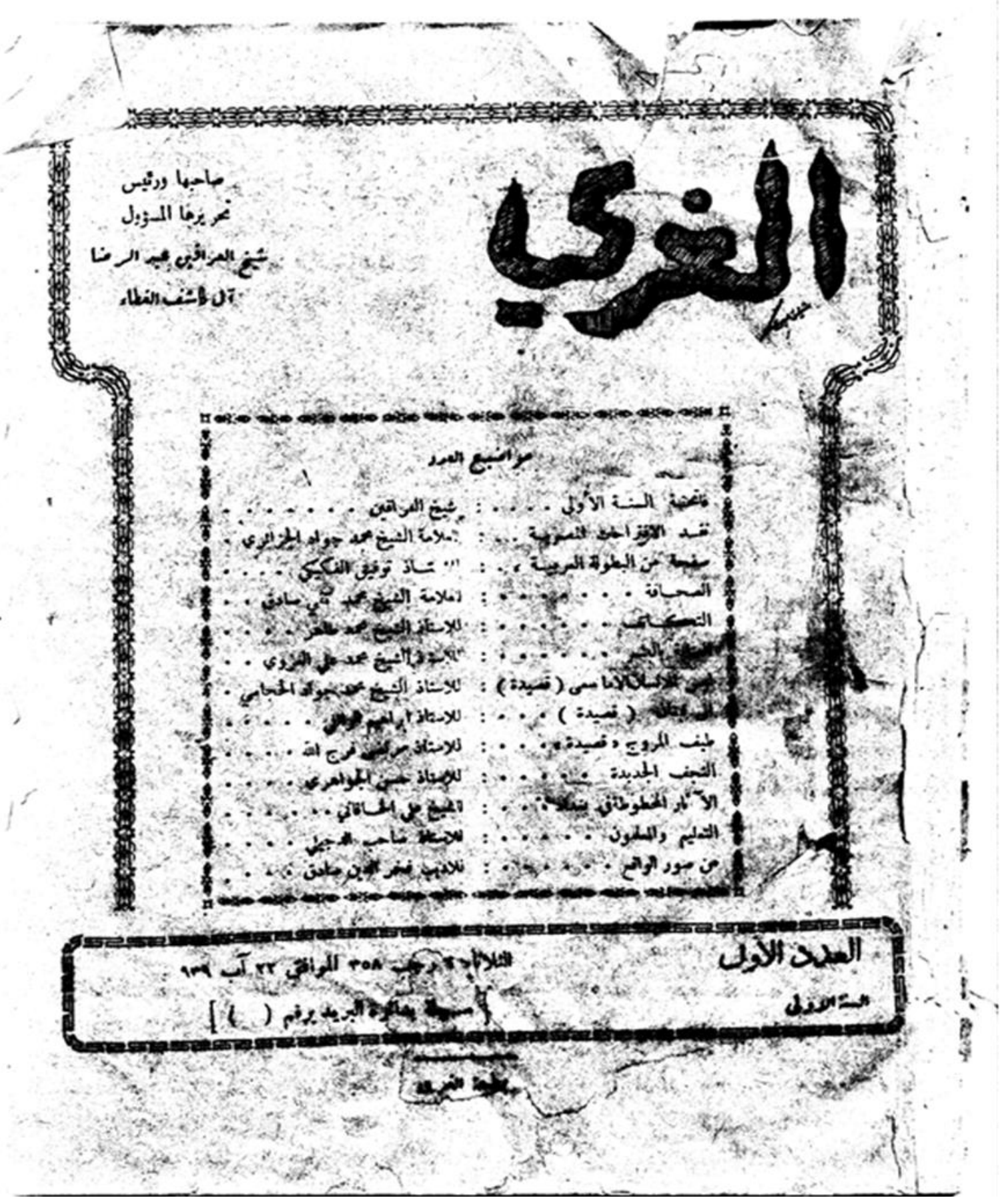


العدد(22) يوليو 2021

ISSN: $2415-4822$
Volume (22) July 2021

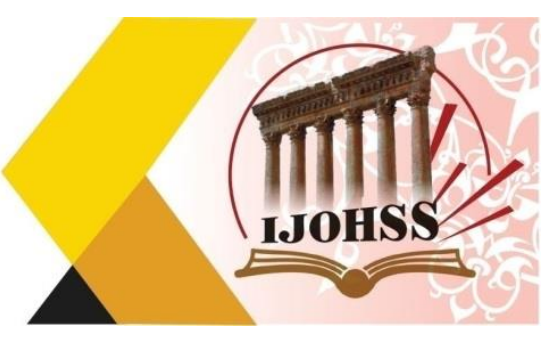

الهوامش

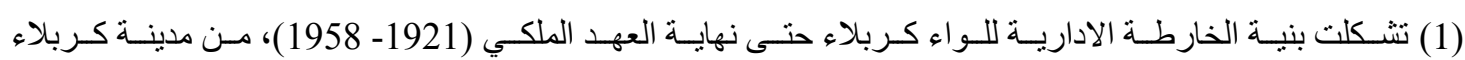

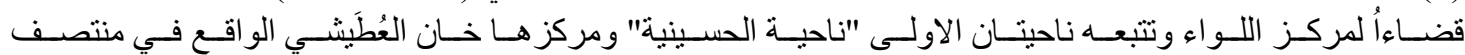

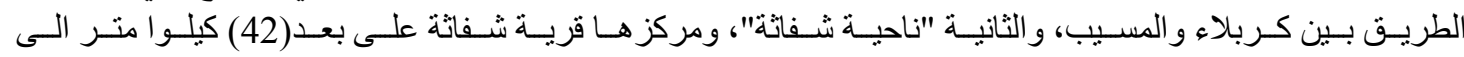

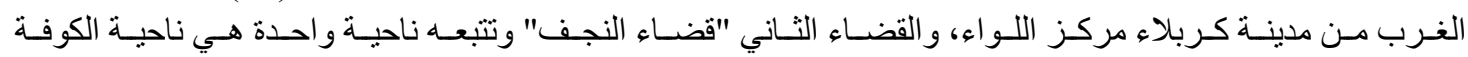

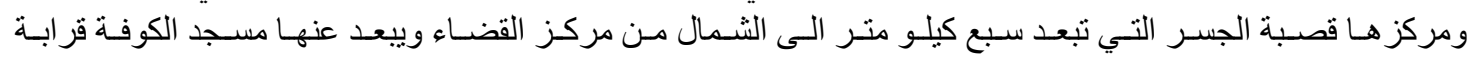

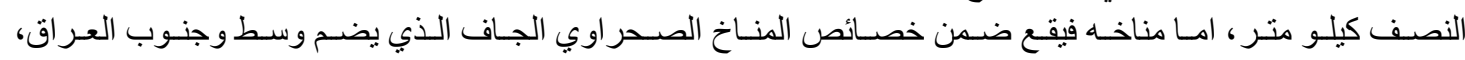

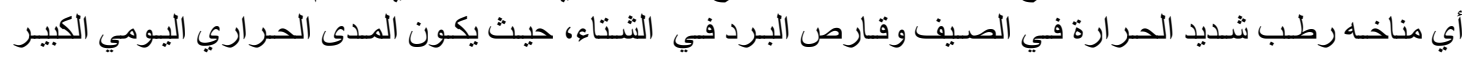

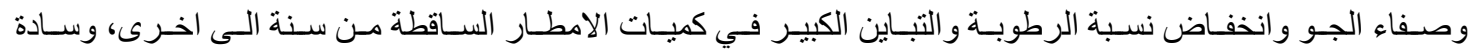

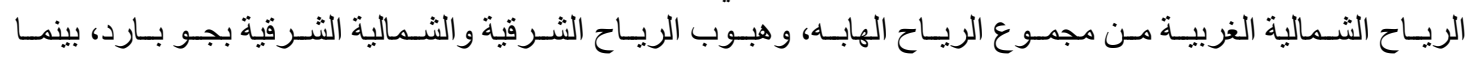

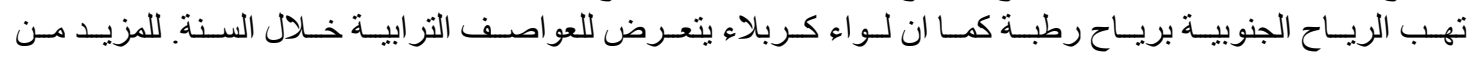

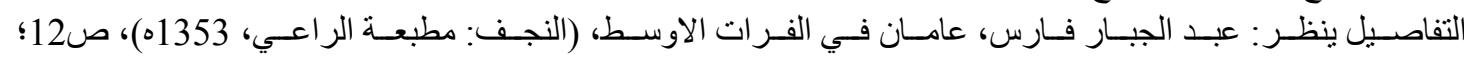

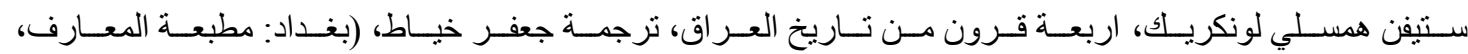

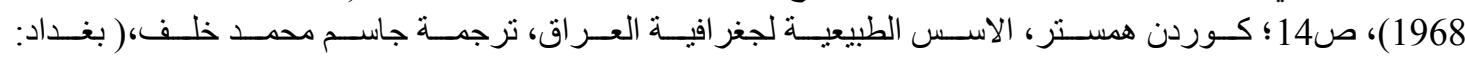

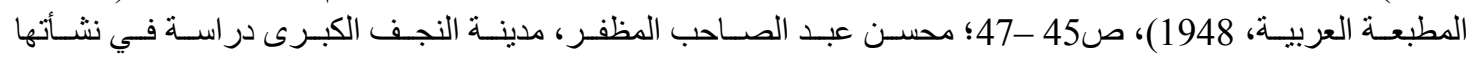

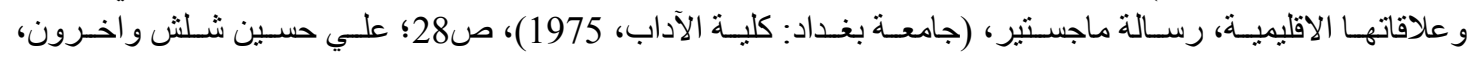

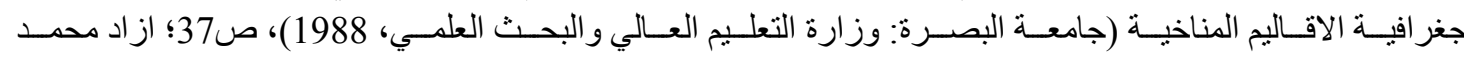

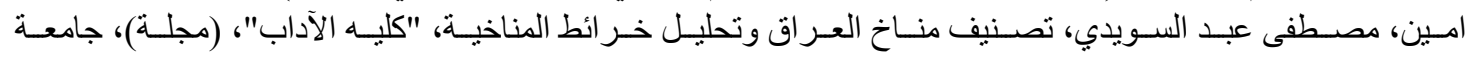

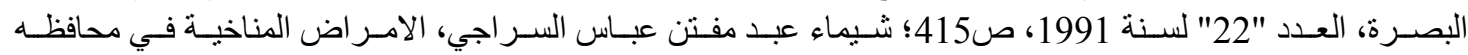

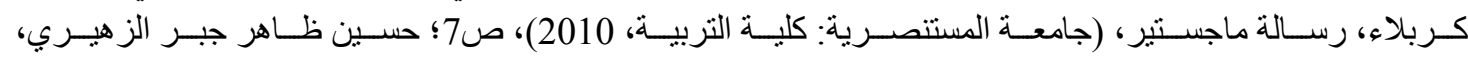

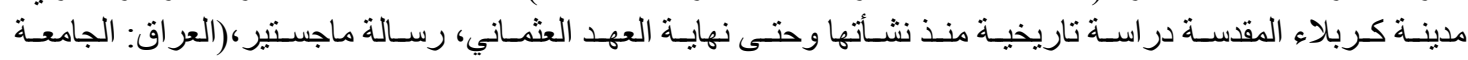

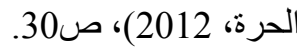

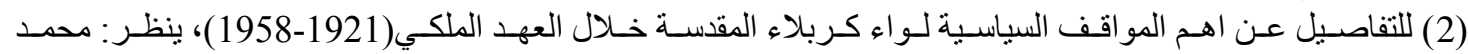

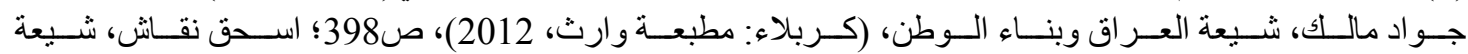

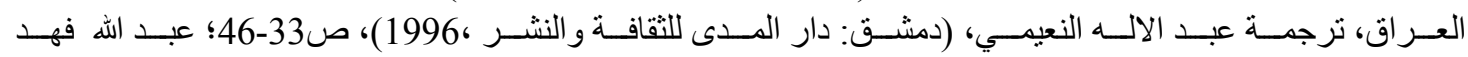

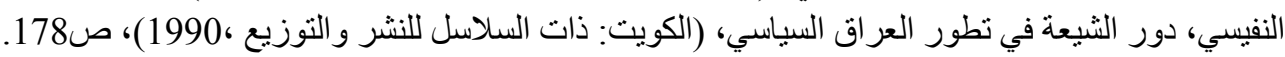

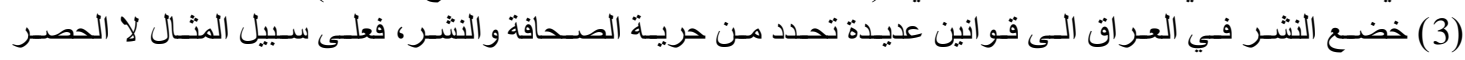

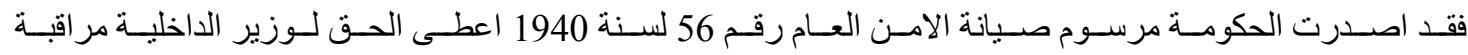

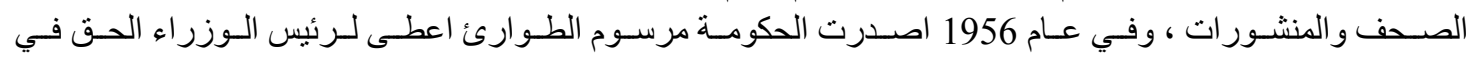

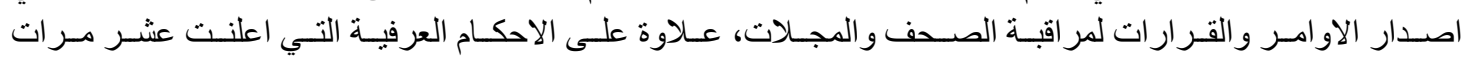

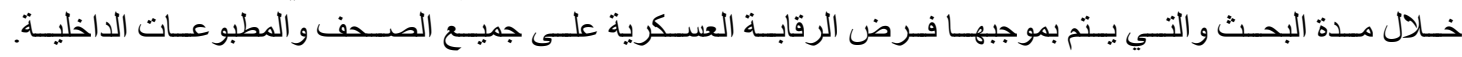

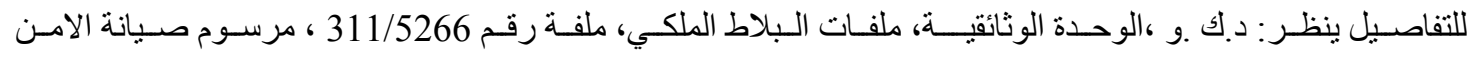

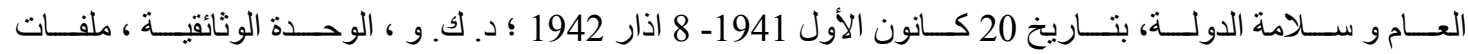

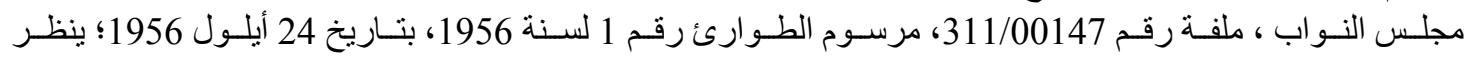

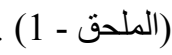

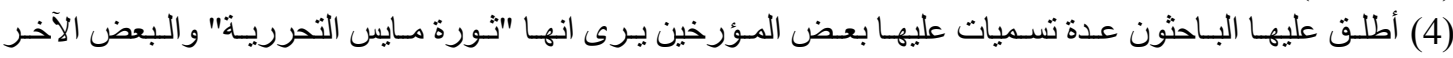

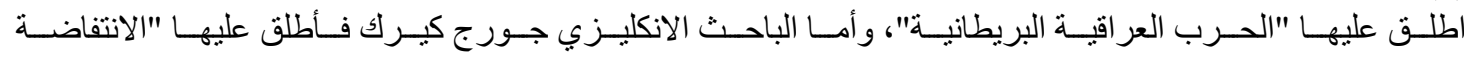

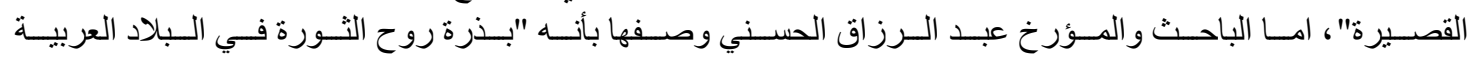

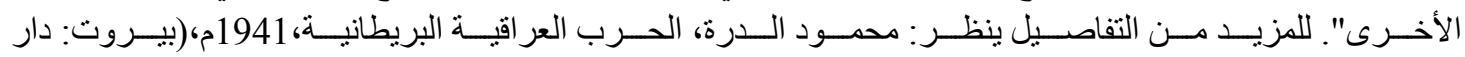

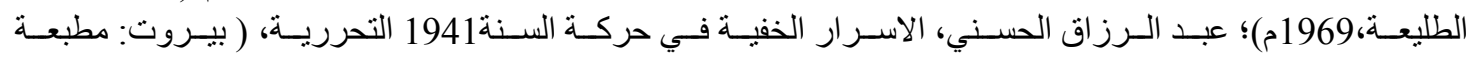




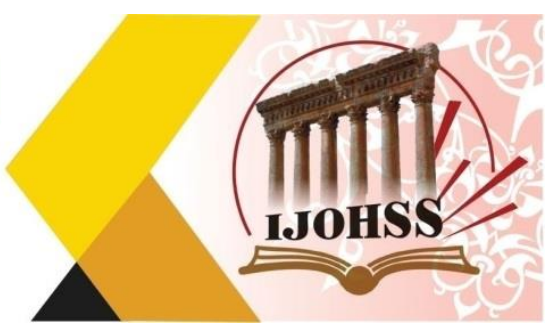

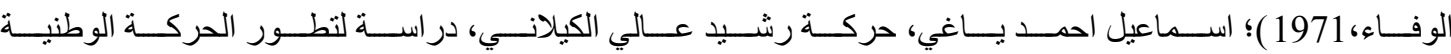

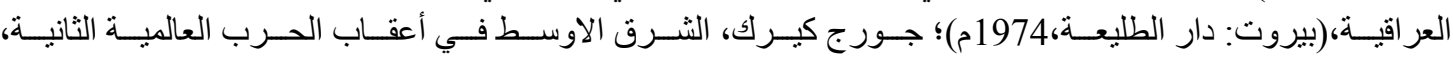

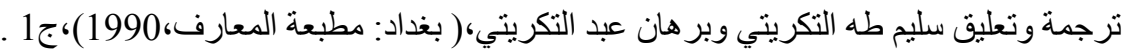

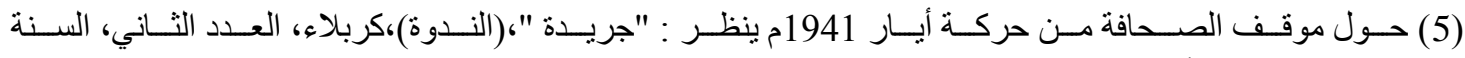

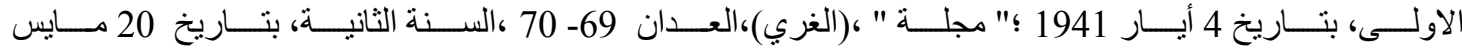

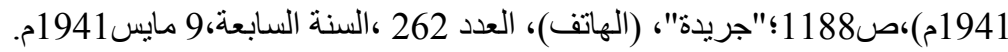

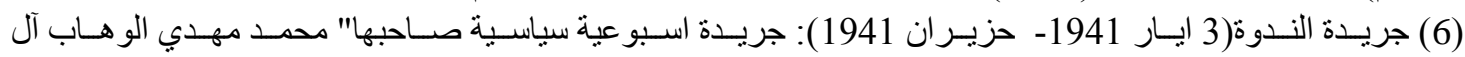

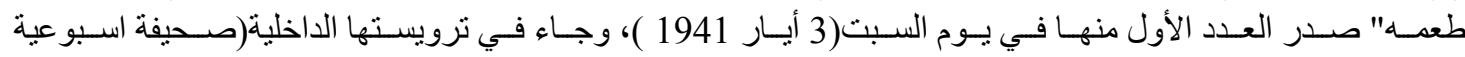

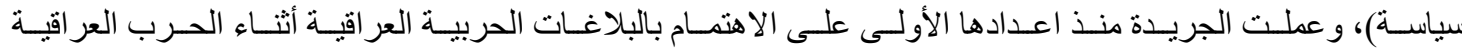

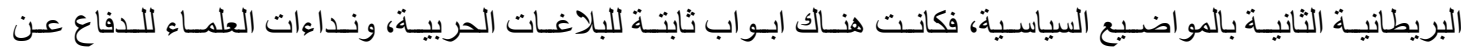

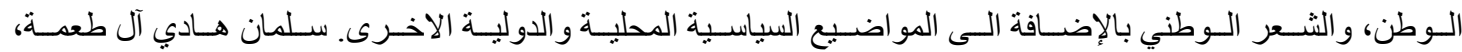

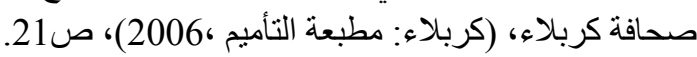
(7) للتفاصيل ينظر : "جريدة"، (الندوة) ، كربلاء ، العدد الاول ، بناريخ 7 حزيران 1941، 1941؛ (ملحق -2).

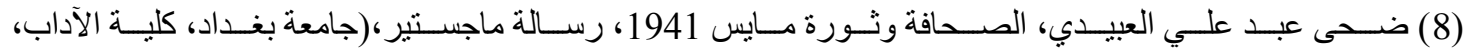

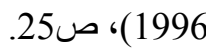

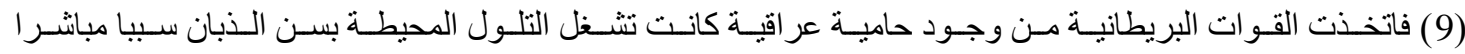

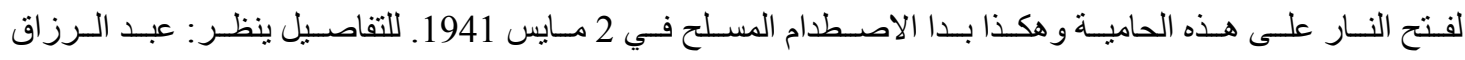

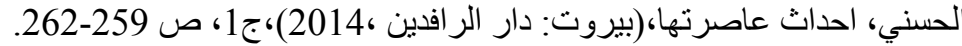

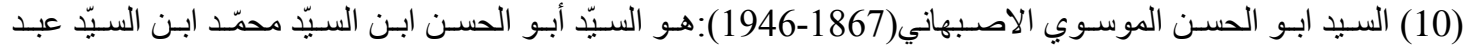

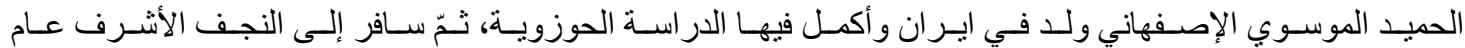

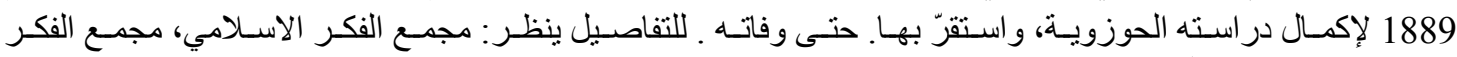

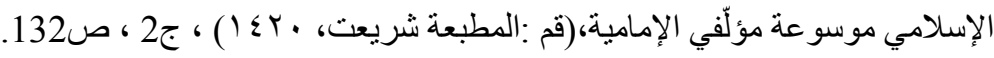

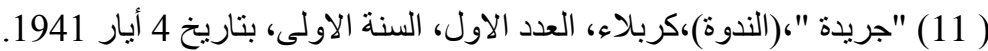

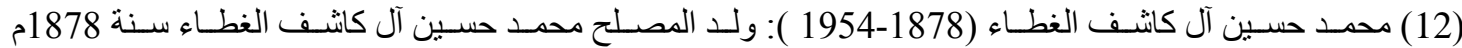

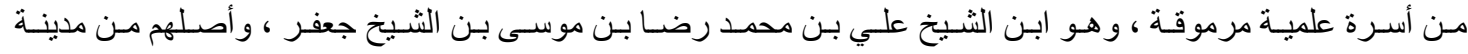

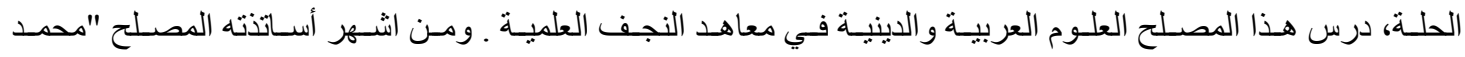

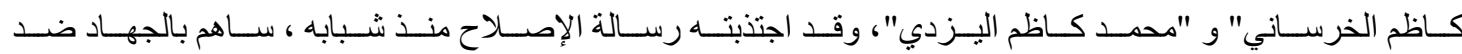

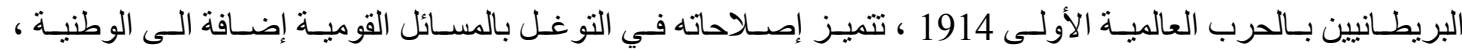

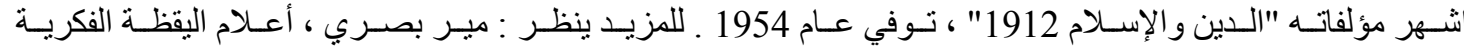

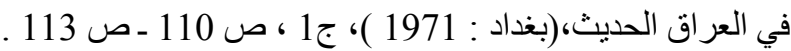

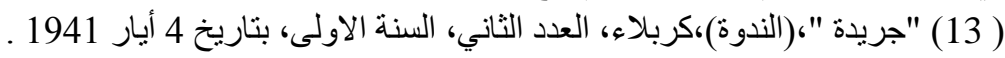

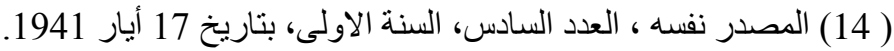

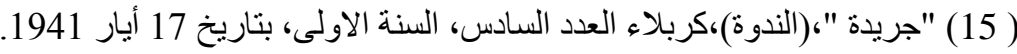

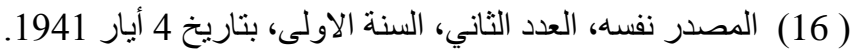

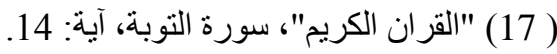

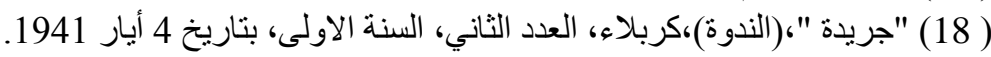

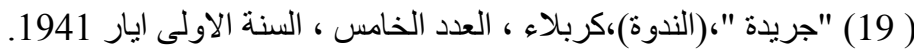

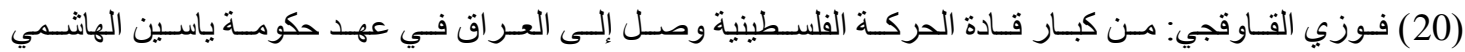

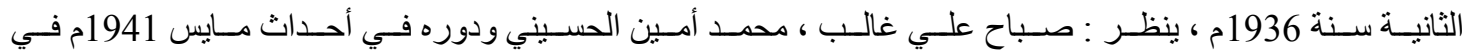

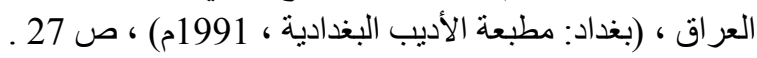




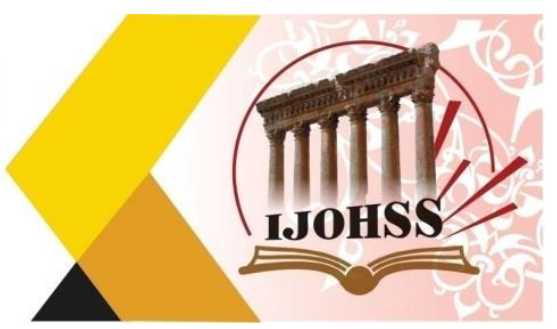

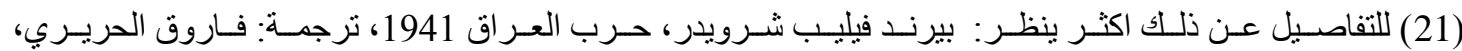

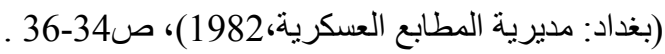

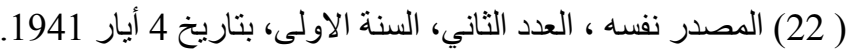

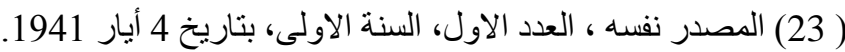

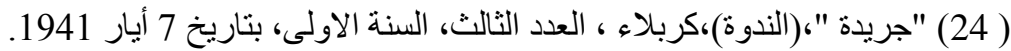

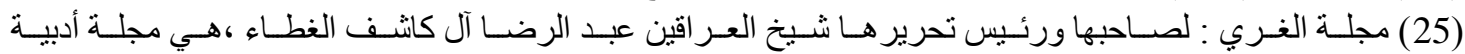

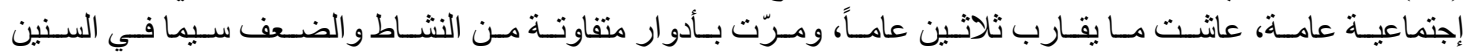

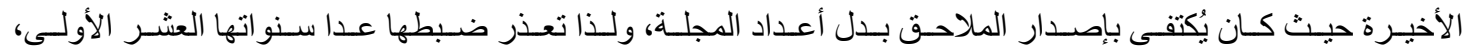

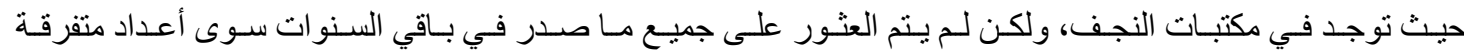

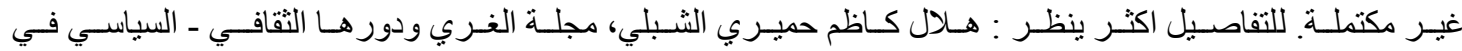

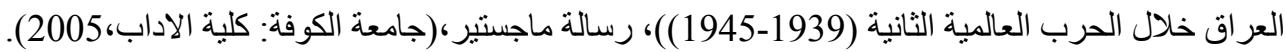

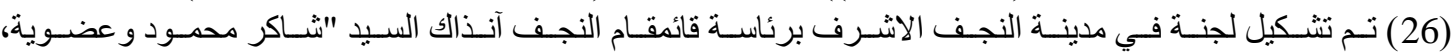

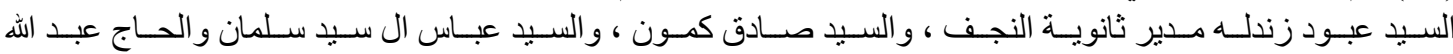

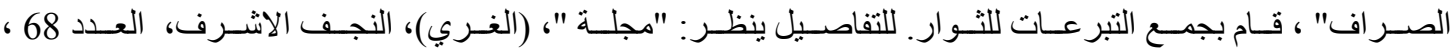

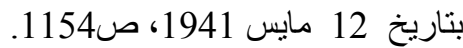
(27) المصدر نفسـ، ص1152 (28)

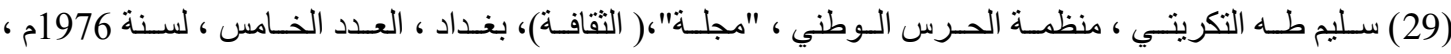
ص ص 152-149

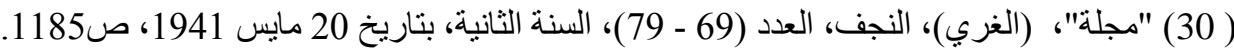

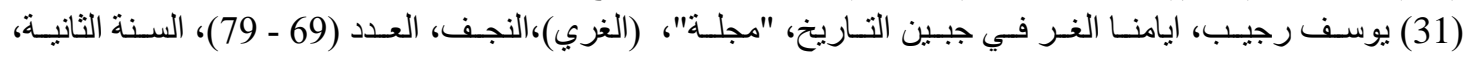

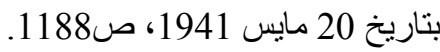

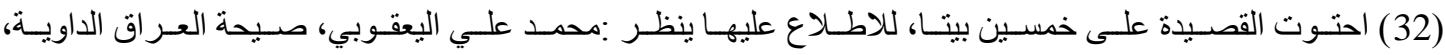

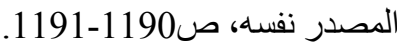

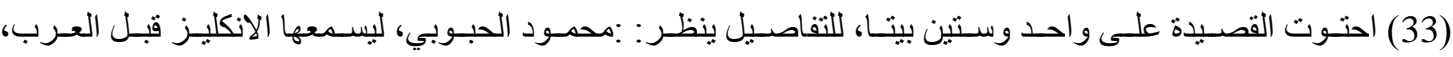

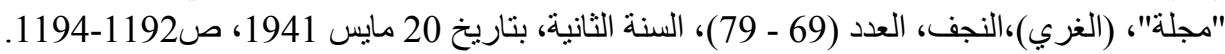

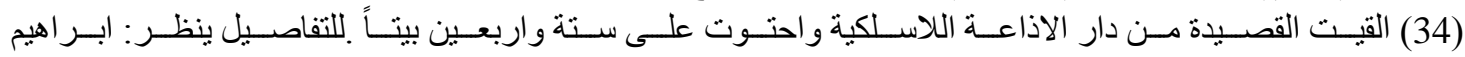

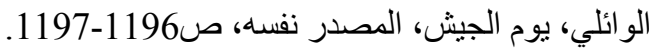

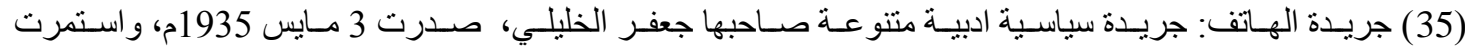

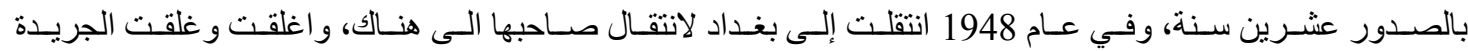

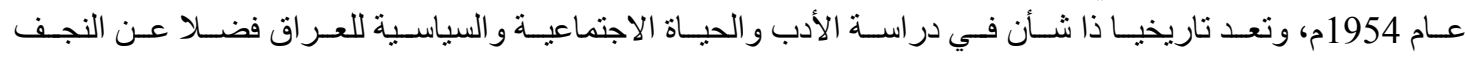

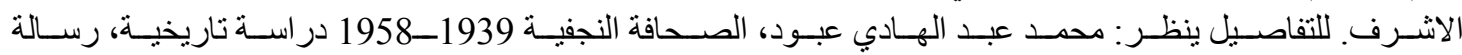

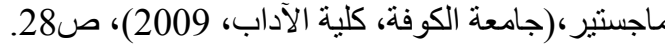

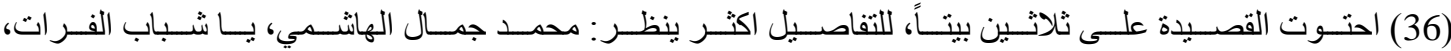

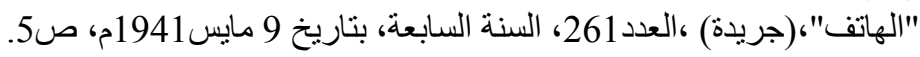




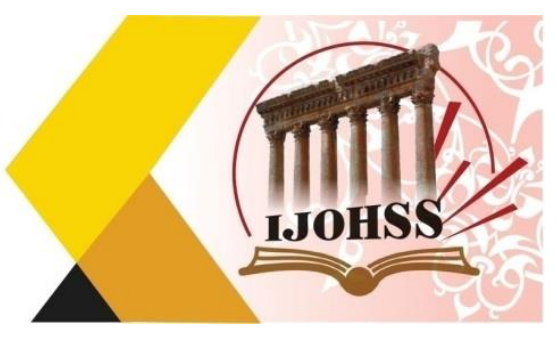

المصادر والمراجع

- كتاب الله (عز وجل) القرآن الكريم.

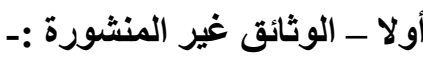

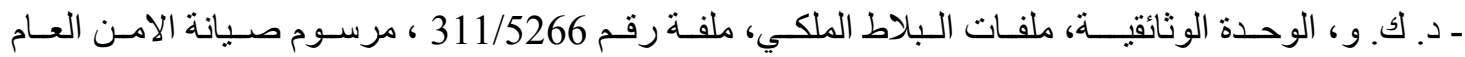

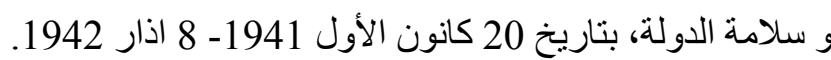

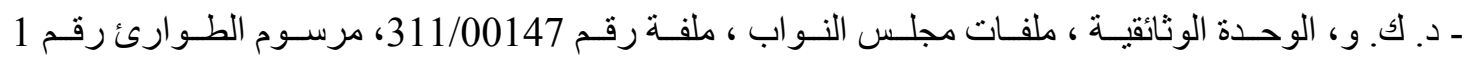

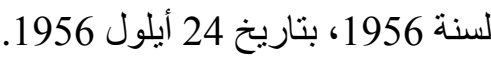

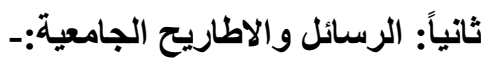

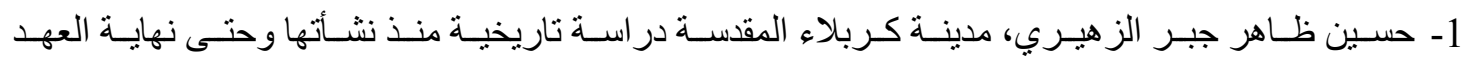

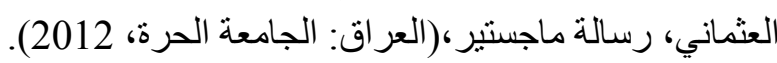

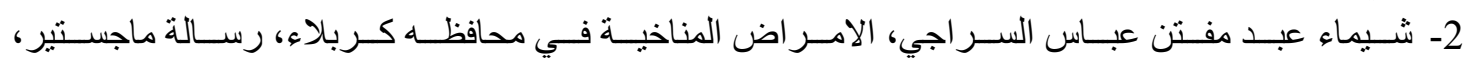
(جامعة المستصرية: كلية التربية، 2010).

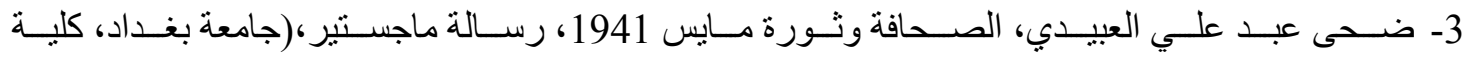

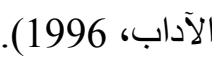

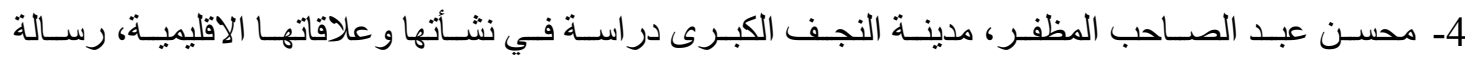
ماجستير، (جامعة بغداد: كلية الآداب، 1975).

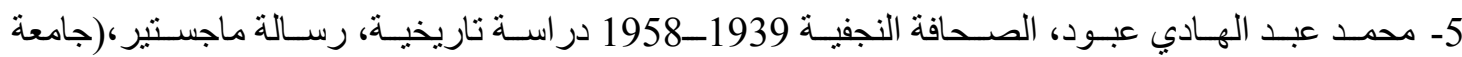

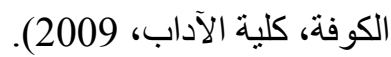

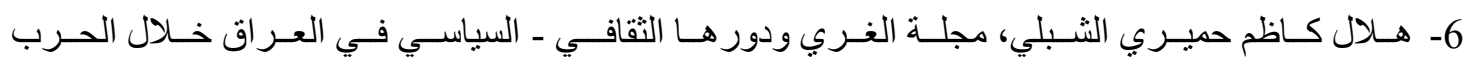
العالمية الثانية (1939-1945))، رسالة ماجستير، ،(جامعة الكوفة: كلية الاداب،2005).

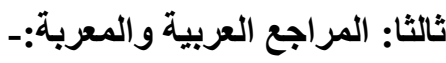

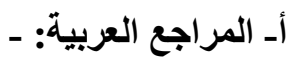

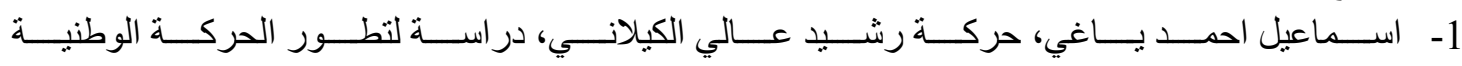
العر اقية،(بيروت: دار الطليعة، 1974م). 2- 2- سلمان هادي آل طعمة ، صحافة كربلاء، (كربلاء: مطبعة التأميم ،2006).

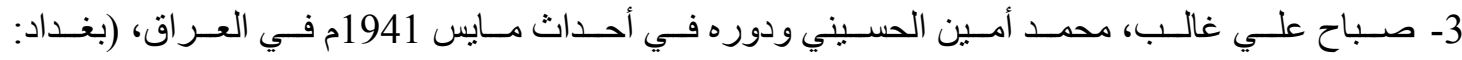
مطبعة الأديب البغادية ، 1991م).

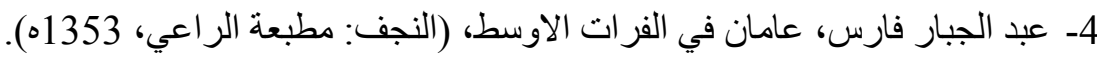

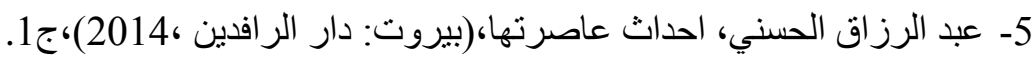

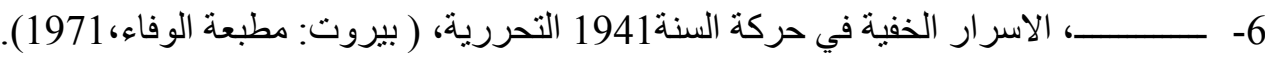

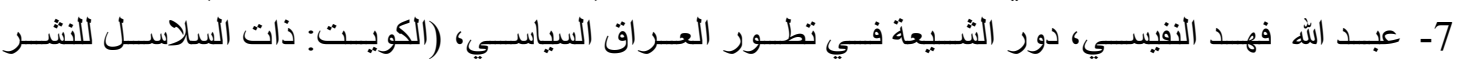
والتوزيع ، 1990).

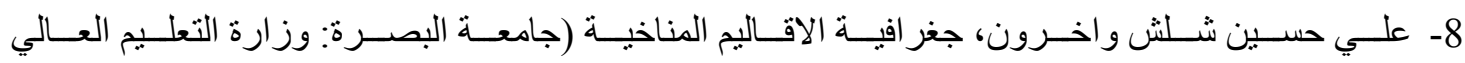
والبحث العلمي، 1988). 


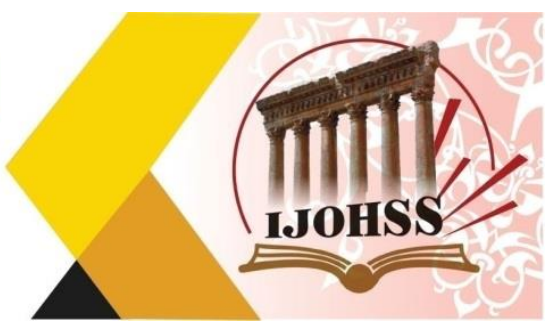

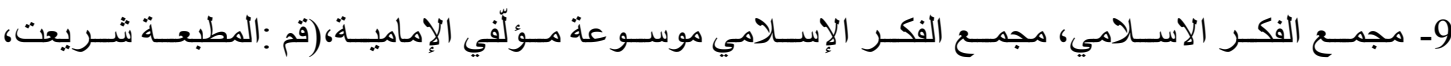
(

10- محمد جو اد مالك، شيعة العر اق وبناء الوطن، (كربلاء: مطبعة وارث، 2012).

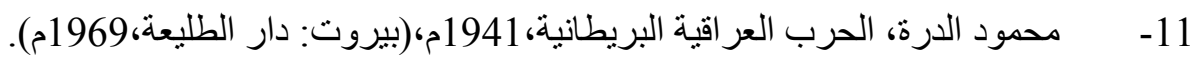

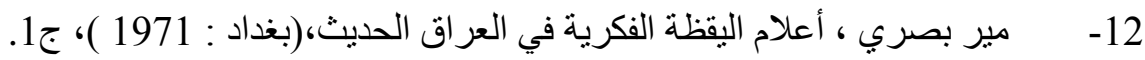

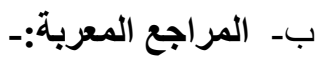

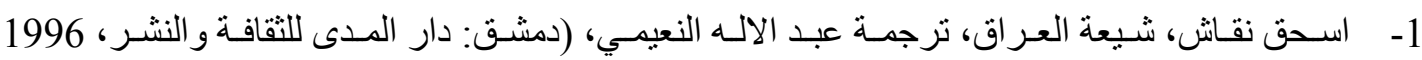

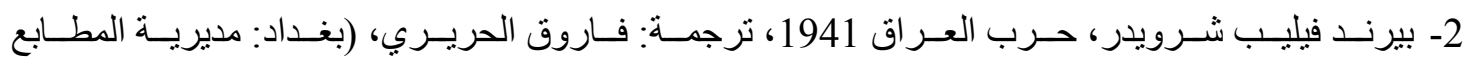

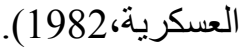

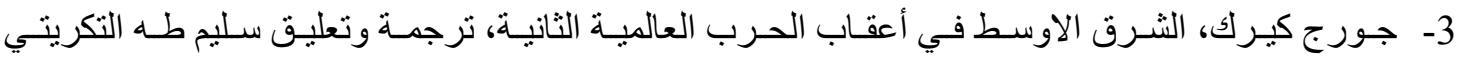

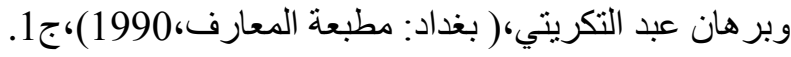

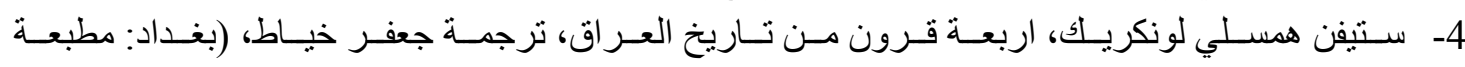

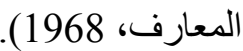

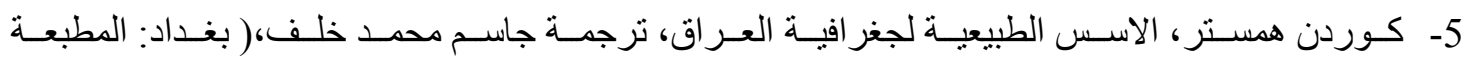

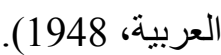

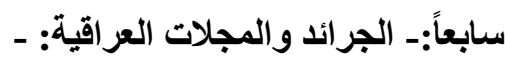

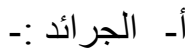

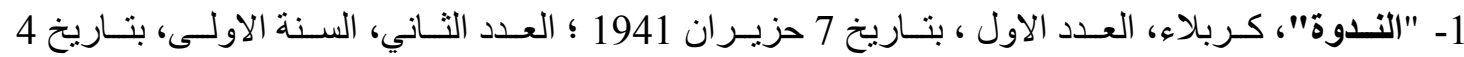

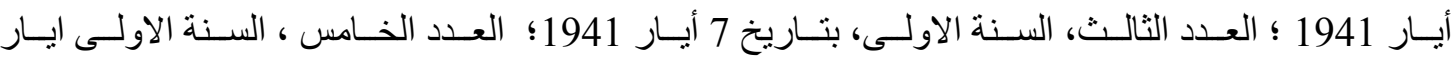

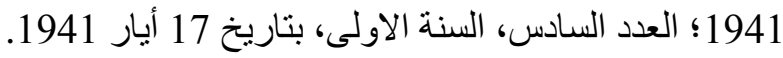

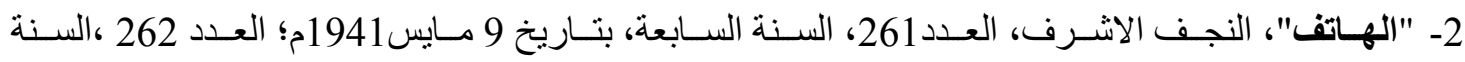

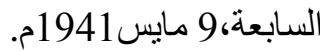

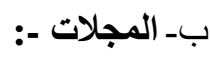

1- "الغــري"، النجــف الاثـــرف، العــد 68 ، بتــاريخ 12 مــايس 1941؛ العـــان 69- 70 ، الســنة

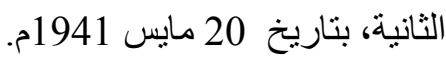

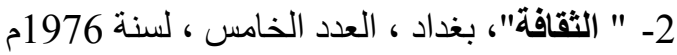

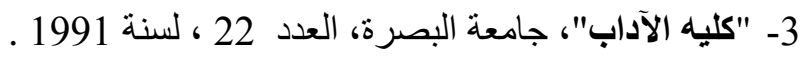

